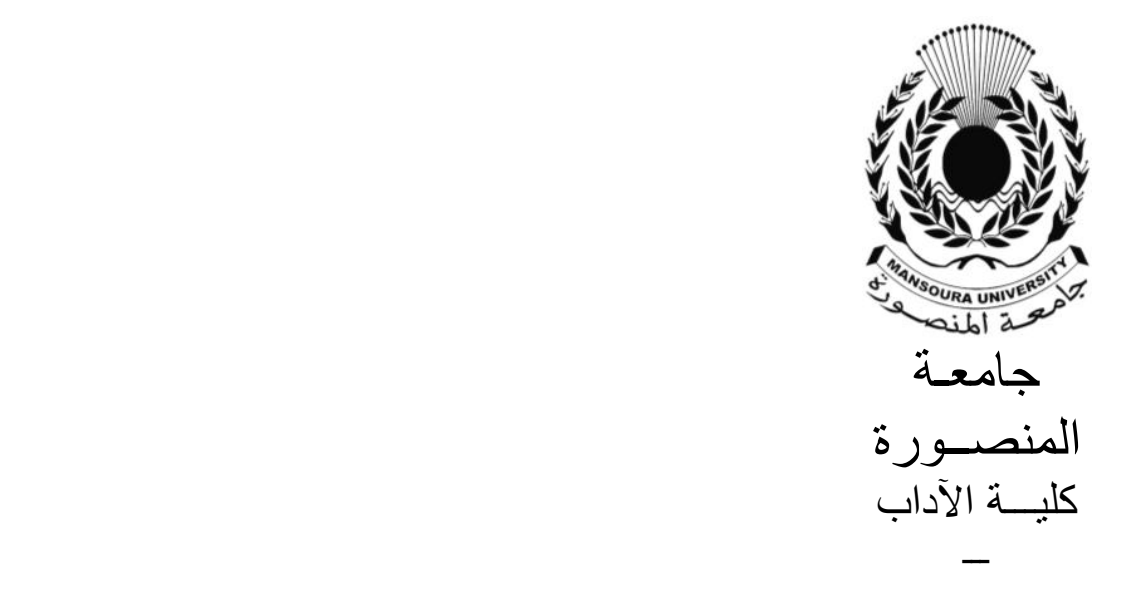

\title{
أشعار التكريم عند إبراهيم بن عزرا
}

\author{
إعـــ/د \\ الدكتور / محمــد فتحـــى البخـــدادى \\ مــرس بقسم اللغـات الثرقيـة \\ كلية الآداب - جامعة المنوفية لية \\ مجــلة كلــــبة الآداب - جامعســة المنصـــورة

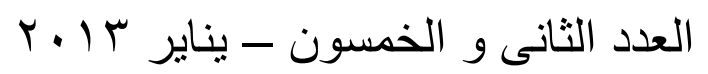




\section{أشُعار التكربيم عند إبـراهيهم بـن عزرا}

الدكتور/ محمد فتحي البغـدادي لهمرون

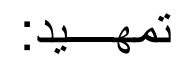

إبر اهيم بن عزر ا: مكانته و أهم مؤلفاته:

هو أبو يتسحاق إبراهيم بن مئير بن عزرا، المعروف بإبراهيم السفارادي، مفسر

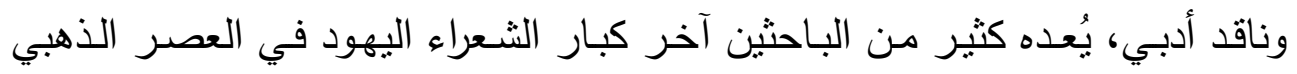

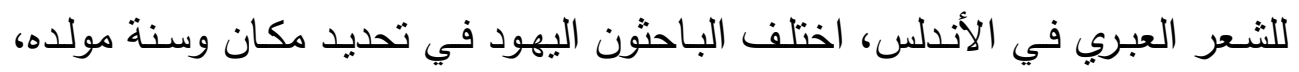

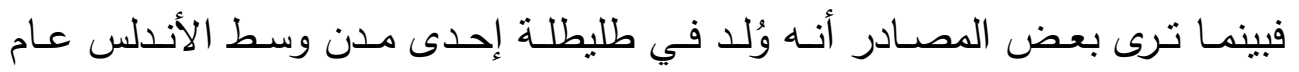

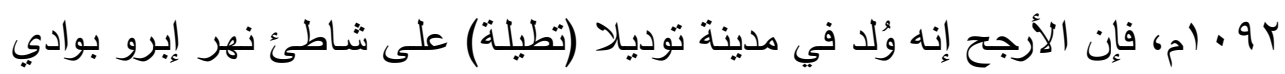

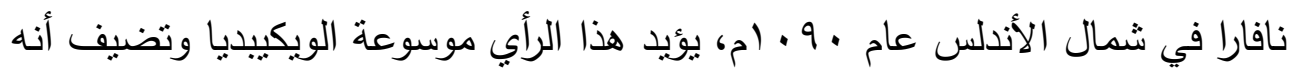

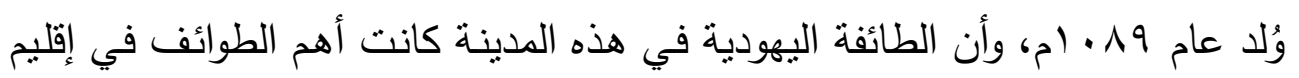
نافارا في العصر الوسيط، ومن أبرز الثخصيات اليهودية التي نشأت في هذه المدينة

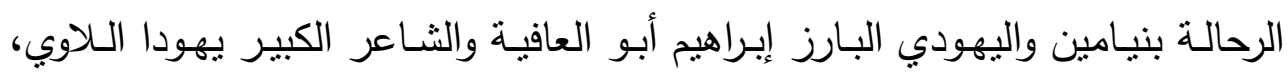

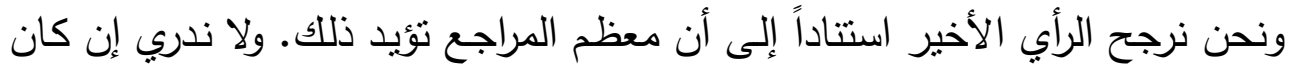

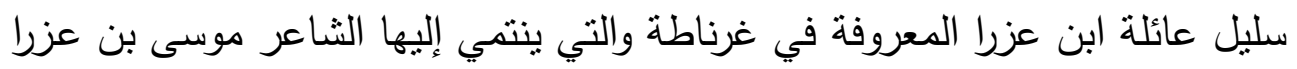
أحد أعلام الأدب العبري في العصر الوسيط، والثناعر نفسه لم يذكر شيئاً عن ذللك. يقول الباحث إسرائيل لفين: "إن إبراهيم بن عزرا عاش سنوات عديدة في أماكن

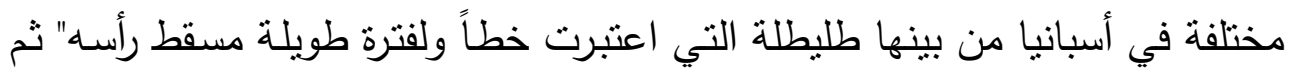
يضيف إنه وُلد في توديلا وهي ذات المدينة التي وُلد فيها معاصره الثـاعر الكبير 
يهودا اللاوي('). وعلى أية حال فإن إبراهيم أمضى سنوات طفولته وصباه في مسقط رأسـه، وككل أبناء العائلات المثقفة تلقى تعليماً منوعاً وثرياً، حتى صسار فقيهاً في إي المؤلفات اليهوديـة عبر عصورها وتعلم أيضـاً العربية ودرس الثقافة العربية وآدابها. ولما بلغ الخمسين من عمره تتقل على مدى خمس وعشرين عاماً بين المدن الأندلسية حيث عـاش فترةً في قرطبـة عاصـمة المرابطين ووصـل إلى الليسـانة ثـم إلى مدن مدن أندلسية أخرى من بينها اشبيلية وغرناطة كما زار مناطق في شمال أفريقيا، فهو إذاً من شعراء الاغتراب في الأدب العبري الأندلسي('). وفي عام • ع ام غادر الأندلس إلى إيطاليا حيث أمضى هناك أكثر من ست سنوات منها خمس في روما، ولكنه سرعان ما شعر بـآلام الغربة في الأماكن الجديدة حتى بين اليهود الذين اختلفت طبيعة حياتهم الروحية عن طبيعة حياة بهود الأندلس، وظل هذا الثعور يلازمه لسنوات عديدة حتى غادر روما إلى لوقا ثم منتوفا ثم غادرها إلى فيرونا حتى رحل إلى فرنسا وأمضى فيها نحو عشر سنوات حيث أقام في نرفونا ثم انتقل إلى روان حتى غادر فرنسا إلى إنجلترا، وليس صحيحاً أنه سافر إلى أرض إضى فلسطين، وإنما ابنه يتسحاق هو الذي فعل ذلك حينما زارها برفقة صـهره يهودا اللاوي. وهكذا لـم يعرف الثـاعر الاستقرار فنتقل بـين أمساكن عديدة وارتبط بعلاقات صداقه مع نبلاء كثثرين من الطوائف اليهودية ومدحهم وكسب عيثه من تعليم تلاميذ التقاهم من أبناء عائلات ميسورة الحال، وبصفة عامـة فقد عانى إبراهيم من الوحدة

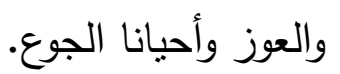

ישראל לווין: שירת תור הזהב: שירי אברהם אבן עזרא، הוצאת אוניברסיטת תל 1 אביב، 2011، עמ' 20.

$$
\text { r د/ عبد الرازق أحمد قنديل: الأدب العبري الأندلسي، الجزء الأول الثعر، .999، 174. }
$$


وخلف ابن عزرا ديواناً يتضـمن نحو ، جr قصيدة في أغراض الثـعر الديني والعلمـاني، فكتب في الألغاز والمديح والاخوانيات والحب والرثاء، وهو أول شـاعر يهودي أندلسي يكتب قصائد في الجدل كما بين الربيع والثتاء، وبين الخمر والخبز، وبين السبت والأعياد، وبين الإنسـان والحيوان، ومسن أثـهر الأغراض التي تتاولها

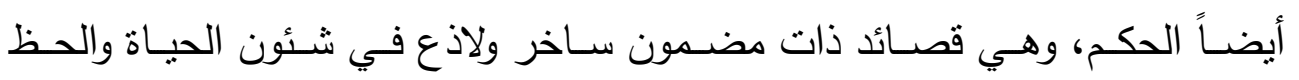
والمتاعب وفي الأغنياء الأغبياء، وهو أيضاً أول من نظم شعراً في لعبة الشطرنج، وقد وصف قواعد تحريك قطعـه وشبه القطع البيضـاء بجيوش المسيحيين والقطع السوداء بجيوش المسلمين.

وهناك أهمية خاصـة لمجموعة صـيرة من القصائد القصيرة التي رثى فيها حظه

وقد صـاغها بأسـاليب إبداعيـة متميزة وبسـخرية ممتزجـة بالدعابـة، وله قصـائد في موضوعات مبتذلة كوصف ثوبـه الرث ووصف ذباب الصيف وقصائد أخرى هاجم فيها البخلاء والأغنياء المتكبرين.

وفي استعراض لبراعته الفنية ألف ما بسمى بقصيدة الثـجرة وهي قصـائد أبياتها

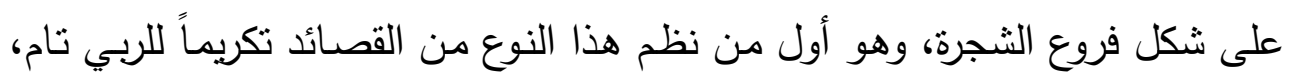
وعلى نهجه نظم تادرس أبو العافية قصيدتين في المديح. وفضلاً عن هذا ألف ما يربو على مائة وثمانين كتاباً، ففي تفاسير أسفار التوراة وضـع تفسيراً لسـفر أيـوب وسـفر الجامعـة، وسـفر أثـعيا بالإضـافة لأسـفار التوراة الخمسة، وترجم من العربية إلى العبرية كتب قواعد اللغة العبرية التي ألفها يهودا بن حيوج. وألَّف في قواعد العبريـة أيضاً كتابيّ الميزان والأسـاس، وكتاب معسول الكلام الذي دافع فيه عن الربي سعديا جاءون ضد انتقادات دوناش بن لبرط، هذا إلى جانب كتاب الفصاحة الذي ألفه عام 7 ـ ا (م. وفي الرياضيات ألف كُتباً أهمها كتاب أساس العدد وكتاب الآحاد، وفي التأمل والفلسفة الدينية ألف كتابين هما: كتاب الاسم الذي 
يتتـاول موضـوعات مختلفـة في قواعد اللغـة وأسـماء الذات الإلهيـة، وكتاب أسـاس الخشـوع. والــي شـرح فيـهـ أسـباب الفـرائض وأثــار بإيجـاز إلـى نظرتـهـ الفلسـفية الأفلاطونية، وربما كانت (رسالة السبت) هي آخر أهم مؤلفاته. وتوفي عام ع 1 ام بعدما أتم عامه الخامس والسبعين، ويكتتف الغموض مكان وفاته أيضاً، فمكان دفنه غير معروف، وهناك من يزعم أنه دُفن في روما، وآخر يزعم

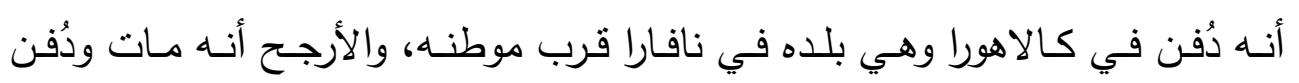
بانجلترا. وجمع رازين أثنعاره الدينيـة والعلمانية وطبعها في حولية بيت مدراث في براغ سلاف بين عامي 1110 ا - 190 (م. وهناك نسخة أخرى أعدها ديفيد كهانا في جزأين. وفي إحدى المخطوطات بالمكتبة الوطنية بفيينا نقرأ العبارة التالية: وفي يوم الاثثين من مارس توفي ابن عزرا وهو في الخامسة والسبعين.

\section{المبحث الأول: أشعار التكريم عند إبراهيم بن عزرا: دراسة في الموضوع}

يتضـمن ديـوان إبراهيم بـن عزرا قسماً خاصـاً يسمى قصـائد التكريم أو الاحترام، يشتمل هذا القسـم على إحدى عشـرة قصسيدة، وهو على الأرجح الأول بين شـعراء اليهـود في الأنـلس الــي كتب أثــعاراً لهـذا الغـرض، وهـذه القصـائد هـي بمثابـة إهداءات من الثاعر لأشخاص مقربين إليه، وهذه الإهداءات هي لمؤلفات مختارة من

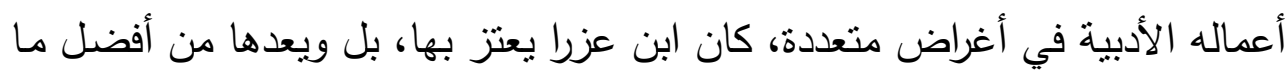

خطت بمينه.

واللافت أن الثـاعر لـ يهد أيـاً مـن هذه الأعمـال لأحد مـن مشـاهير اليهود في

الأندلس، أو لأصدقائه وأسـاتذته ومعلميه فيها، بل وحتى أفراد أسرته ليس لهم فيها

نصيب. وعلى العدوم فإن موضوعاتها متعددة، وذللك على النحو التالي:

1- في التفاسير : تفسير أيوب ونشيد الأناشيد وتفسير التوراة.

r- في التفسير والقواعد: كتاب معسول الكلام وكتاب الاسم. 
ع- في مجال الفلسفة الدينية: كتاب أساس التقوى وكتاب العلل. 0- في الرياضيات: كتابا العدد وأساس العدد. 7- في الفلك: كتاب أداة نحاسية (الإسطرلاب).

وأثنعار التكريم عند ابن عزرا مهداة إلى فئتين، بحيث يحتوي القسم الأول على سبع قصائد مخصصـة لتلاميذه وهم: مئير ، وهليل بن يتسحاق، وبنيامين بن يوآب، وحاييم وحننيا، وشلومو ـ أما القسم الثاني فيحتوي على أربع قصائد أهداها لخمسة من الحكمـاء الذين كان الثـاعر يجلهم ويحترمهم وهـم: الربي يوحنـان بن دفيد، الربي أبراهام بن حاييم، والربي يتسحاق بن يهودا، والربي موشيه بن مئير، والربي يوسف ابن بعقوب.

$$
\begin{aligned}
& \text { ويمكن استعراض هذه الإهداءات على النحو التالي: } \\
& \text { أو لا: أشعار مهداة إلى تلاميذه: }
\end{aligned}
$$

بعد أن غادر الثـاعر الأندلس عـانى كثيراً في حياته، وذاق مـرارة الفقر والعوز . وعمد إلى توطيد صداقته مـع نبلاء كثيرين من الطوائف اليهوديـة فمدحهم وتقرب إلبهم، ولجأ لكسب عيشـه من تعليم تلاميذ التقاهم من أبناء عائلات يهوديـة ميسورة الحال علوم الثربعة اليهودية واللغة العبرية. وكان يتقاضى أجراً نظير ذلك. ولا يتوفر لدينا الكثير عن هؤلاء التلاميذ، ولا المناسبات التي أهداهم فيها هذه المؤلفات، غير أنه كان حريصاً في كل مرة على تأكيد تميزهم عمن سواهم، بصغر سنهم ورجاحة عقولهم. ويجب أن نأخذ في الاعتبار أن كل هذه الإهداءات لم تكن دائماً لمؤلفات انتهى منها الثـاعر بالفعل، ففي بعض الأحيان كان يعد بتأليفها استجابة لطلب الآخرين وبخاصة تلاميذه. 
(أ) يهدي الثـاعر في القصيدة الأولى كتابه العدد لأحد تلاميذه ويدعى مئير ، وهي عبارة عن مقطوعة من بيتين، نوه فيهما الثاعر إلى أنه يهدي كتابه لتلميذه مئير • و نحن بدايةً لا نعرف من هو مئير هذا، ولا سبب اعتزاز الثـاعر بـه للحد الذي جعله

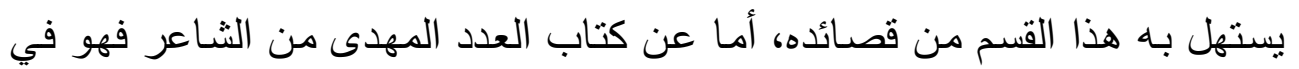
مجال الرياضيات، أحد المجالات التي برز فيها الرجل وكان لله فيها إسهام، وقد ألفه هنه ابـن عزرا في فيرونـا عـام • 1 ام لتعليم الحسـاب، ويقع في سبعة فصـول. يقول الثاعر : n

וְתִמְצָא בוֹ לִכָל מִoְפּר תְכוּנָה

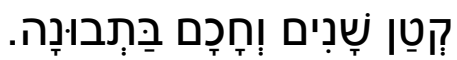
وستجد فيه لكل رقم خاصية صغير السن ولكنه راجح العقل

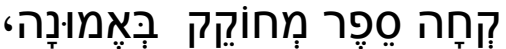

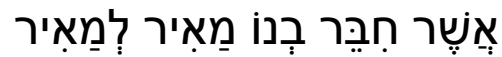

المقطوعـة عبـارة عـن بيتين، الأول تحـدث فيـه الثـاعر عـن الكتـاب المهـدى منـــ لتلميذه مئير ، والثاني خصصه للحديث عن تلميذه. واللافت أنه أثنى على مؤلفه وزعم أنه يقنن بثقة، وأنـه مؤلف جامع لكل خصائص الأرقام، ومـع علمنا بـأن ابن عزرا اشتخل لفترة بالتدريس، وكان معلماً للعبرية فلا نستبعد أن يكون درَّس الحساب أيضاً، ومن هنا فالأرجح أن يكون الكتاب لتعليم الحساب للمبتدئين، وليس مرجعاً أساسياً في علم الرياضيات مثنلا. (ب) والقصيدة الثانيـة إهداء لكتاب (أسـاس العـدد) مـن الثـاعر لتلميذه هليـل بـن يتشـاق، وهي عبارة عن بيتين، جعلهما الثـاعر للنتاء عليه، في إثـارة إلى رجاحة عقله مع صغر سنه، حيث قال:

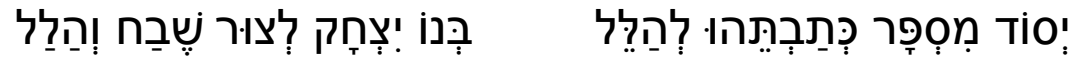

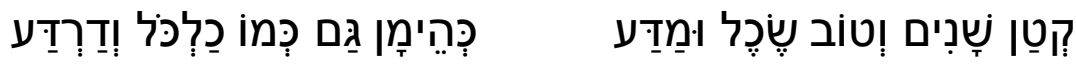
أسـاس العدد ألفته لهليل ابن بتسحاق لإنشاء المديح والثناء 


$$
\text { صغير السن ذو عقل وعلم عيمان وأيضاً منل كلكول ودردع }
$$

(ج) ولما كان ابن عزرا يستمد جزءاً كبيراً من شهرته من مؤلفاته في تفاسير التوراة التي أثناد بها حكماء عصره، حتى أن الربي موسى بن ميمون أمر ابنه بأن يقرأ كتب إبراهيم بن عزرا فقط، وتعتبر شروحه من أفضل ما كُتب في العصر الوسيط به بـ في هذا الثـأن(')، وقد تمسك فيها بـالمعنى الحرفي للنصوص متفاديـاً التأويـل والمبالغة، فظل بذلك أميناً للتراث اليهودي، شديد الانتقاد للذين لا يتمسكون بهذه الحرفية في شرح وتفسير النص التوراتي. ومن هؤلاء الربي يونا بن جناح الذي قال

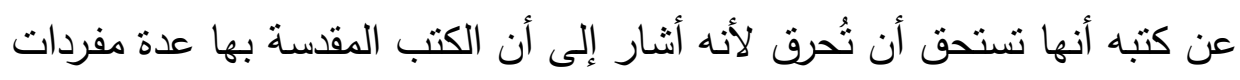
لم يوفق الكُتاب فيها ويجب استبدالها. وقد كتب ابن عزرا هذا التفسير في روما

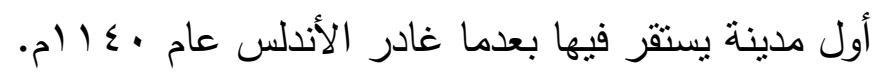

وتتضـن قصيدته الثالثة إهداء الثـاعر تفسيره لسفر أيوب لتلميذه بنيامين بـن يوآب، حيث قال:

\begin{tabular}{|c|c|}
\hline 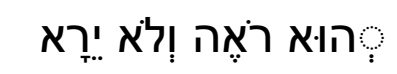 & וְּננוּ כָבוֹד לְאֵל נוֹרָא \\
\hline וְדַרְכּוֹ לְאֶנוֹש הֹוֹרָה & וְהוּא נִשְׁגָּב בְּחָכְמָתוֹ \\
\hline 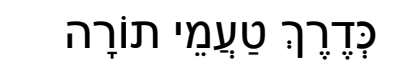 & 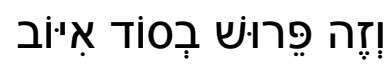 \\
\hline סִפָרַדִי בְּנוֹ עֶזְרָא & לִאַבְרָהָם בְּנוֹ מִאִיר \\
\hline 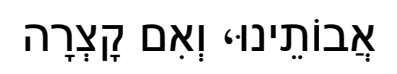 & בְּרוֹמִי חִבְרוֹ בִלְּשוֹן \\
\hline וְלְצִפִירָה מְפֹאָרָה & הֶיוֹתוֹ לַעַטְרֶת הוֹד \\
\hline בְנוֹ יוֹאָב אַבִי מִשְׁרָה & לִבְינְיָמין יְְליד חָכְמָה \\
\hline
\end{tabular}

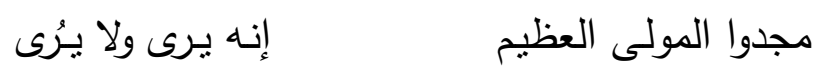




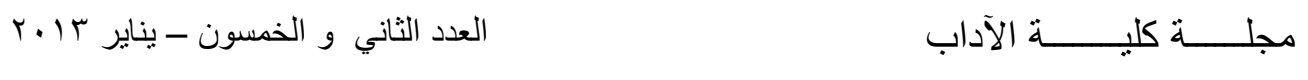

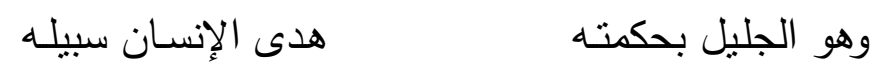

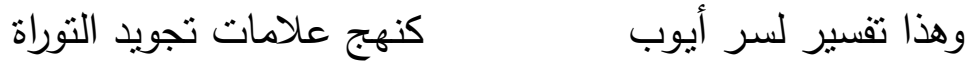$$
\text { (الذي ألفه) إبراهيم بن مئير السفارادي بن عزرا }
$$

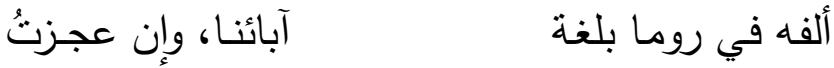

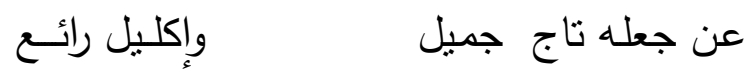

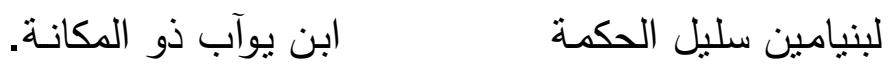

يمكن تقسيم القصـيدة إلى ثـلاث أجـزاء على النحو التـالي: الجـزء الأول يشـمل البيتين الأول والثاني، وهما بمثابـة استهالال ديني بـارع كرسـه الثـاعر للحديث عن المـولى تبـارك وتعـالى، العظيم، الجليـل، الهـادي إلى سـواء السبيل. والجزء الثاني وبشمل الأبيات من الثالث حتى الساد، وهو لب القصيدة وقد أفرده الثاعر للحديث عن تفسيره لسفر أيوب ومكان تأليفه في روما. واللافت أن صياغة هذا الجزء تذكرنا بالنصب التذكاري الذي يخلد حدثاً معيناً في الزمـان والمكان، فهنا موضـع التأليف رومـا، والمؤلف هو إبراهيم بن عزرا بطبيعة الحال، والذي أطلات على نفسـه إبراهيم السفارادي، والتلميذ هو بنيامين بن يوآب، ولغة الكتاب هي العبرية وموضوعه تفسير سفر أيوب. بل ونجده يصرح بأنه ربما قصَر في بعض جوانبه فيلتمس لذلك عذراً.

\begin{tabular}{|c|c|}
\hline וְאוֹדֶנוּ בָרָאטש & אַנִי אֶל אֵל אֶדְרוֹטש \\
\hline 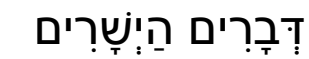 & 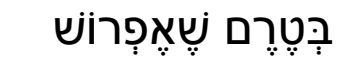 \\
\hline בְנוֹ הְֶֶכִּים אוֹתוֹ & לְפָנִנים בִּפְדוֹתוֹ \\
\hline نשֶמוּרַה לְדוֹרִים & וּמִימִינוֹ דַתוֹ \\
\hline
\end{tabular}

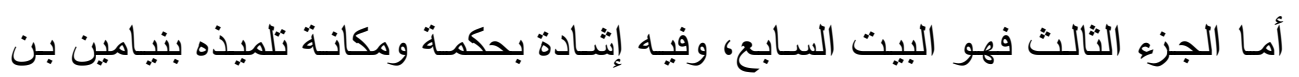
يوآب. (د) وأهدى ابن عزرا تفسير سفر نشيد الأناثيد لتلميذه بنيامين حيث قال: 


$$
\begin{aligned}
& \text { לְבִינְיָמִין צָעִיר } \\
& \text { וְרוּחַ חַן הִּעִיר }
\end{aligned}
$$

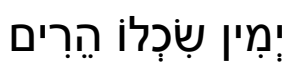

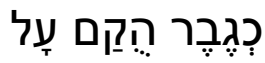

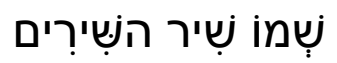

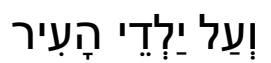

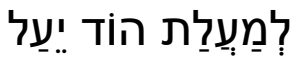

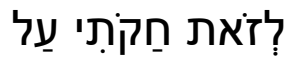

$$
\begin{aligned}
& \text { أتوجه إلى المولى عز وجل وأحمده في البداية }
\end{aligned}
$$

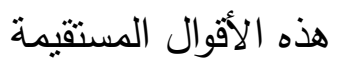

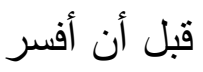

$$
\begin{aligned}
& \text { ابنه وجعله حكيماً } \\
& \text { من قبل افتدى } \\
& \text { المحفوظ على مدى الأجيال } \\
& \text { وأعطى بيمينه دينه } \\
& \text { بنيامين الصغير } \\
& \text { وأسبغ نعمته على } \\
& \text { من كل أبناء المدينة } \\
& \text { وجعل حكمته أعلى } \\
& \text { كرجل سما وارتفع } \\
& \text { ورفعه إلى أعلى منزلة } \\
& \text { مثل نشيد الأناشيد } \\
& \text { ولذا قلدت لأجله }
\end{aligned}
$$

هذه القصيدة يمكن تقيمها إلى جزأين، الأول كالمعتاد ذو صبغة دينية استهله الثـاعر بحمد الله والثتاء عليـه، ثم انتقل في الجزء الثاني إلى الثـاء على تلميذه بنيامين مشيراً إلى فضل الله عليه، فقد وهبه الحكمة ورفع منزلته. واللافت في هذه القصيدة انتقال الثـاعر المفاجئ من الحديث عن نفسه إلى الحديث عن الغائب، وما صاحب ذلك من غموض يلف المعنى في البيتين الثالث والرابع، فلا نعرف من المفتدى، الذي صار فيما بعد حكيماً، ولعل المقصود التلميذ بنيامين. ثم يعود الثاعر للحديث عن نفسه في البيت الأخير ، وفيه تصريح منه بأنه يهدي هذا التفسير لتلميذه دعماً له وتشجيعاً. 
يبقى أن نسلم بأننا لم نلحظ علاقة ما تربط بين التلميذ والتفسير المهدى له من قبل

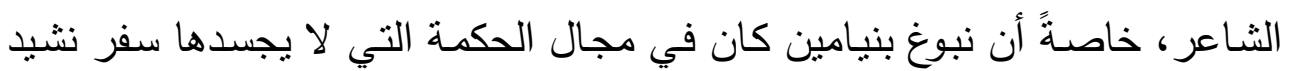

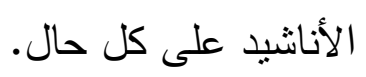

(هـ) أما كتابه معسول الكلام (שפת יתר) فقد أهداه الثاعر لتلميذه حاييم، فقال:

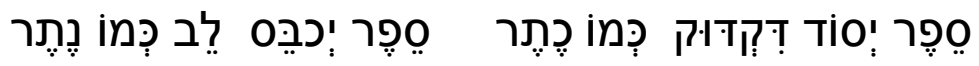

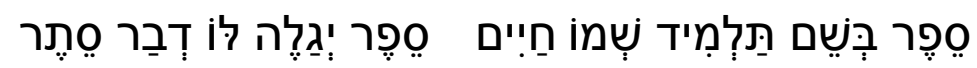

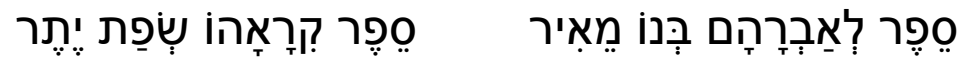

$$
\begin{aligned}
& \text { كتاب أساس القواعد كالتاج كتاب يغسل الفؤاد كالصابون } \\
& \text { كتاب باسم تلميذ يُدعى حاييم كتاب يكثف له سراً }
\end{aligned}
$$

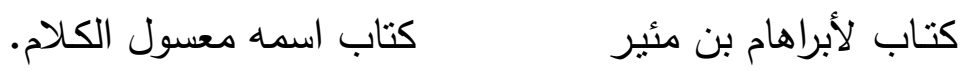

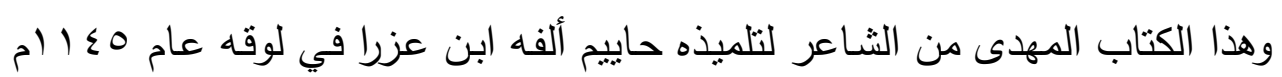

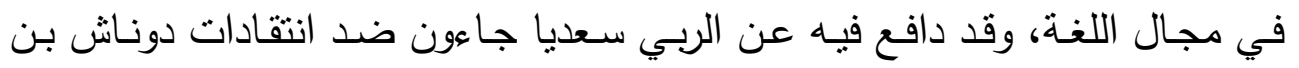

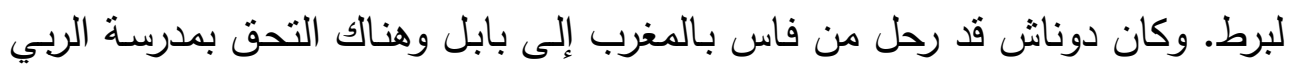

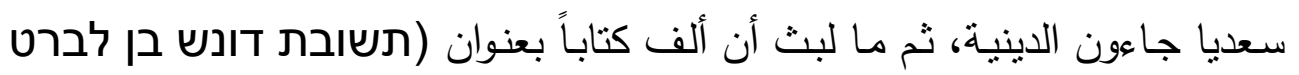

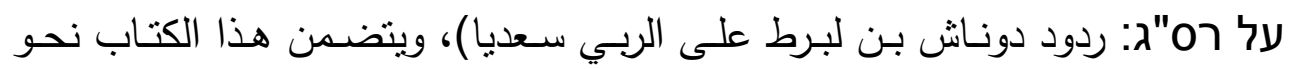
مائتي ملاحظة على كتاب معلمه القديم الربي سعديا في قواعد اللغة العبرية(').

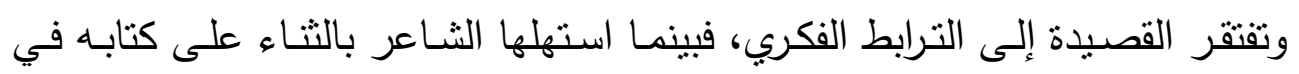

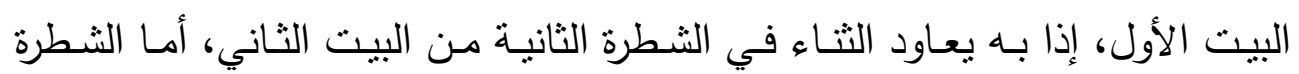
الأولى من البيتين الثاني والثالث فقيهما ذكر من أهدى والمهدى إليه ونحو ذلك. للك. 
والغريب أن هذه القصيدة تتفرد بين جميع قصائد هذا القسم بأنها الوحيدة التي تبدأ كل

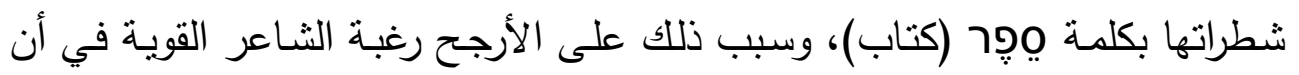
يعدد مزايا كتابه.

(و ) وعُرف عن ابن عزرا اهتمامه بمجالي الفللك والتتجيم، ومما ألفه الرجل في علم

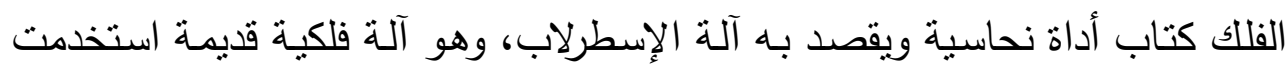

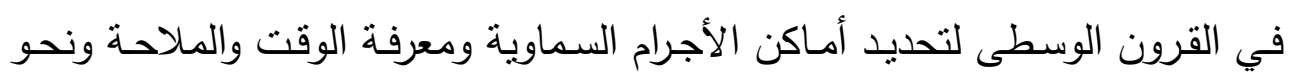
ذلك، وقد أهدى الثاعر كتابه هذا لتلميذه حننيا، حيث قال:

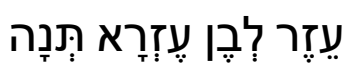

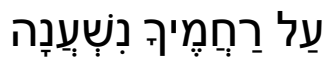

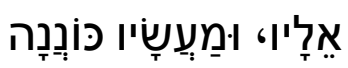

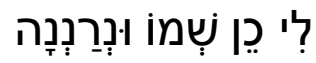

$$
\text { أن تساعد ابن عزرا }
$$
واعتمدت على رحماتك وسـدِّد أفعالـه وأسعدني به كاسمـه.

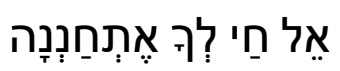

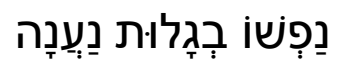

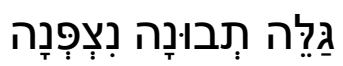

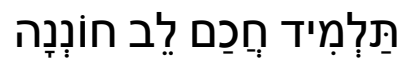
الهي أتوسـل إليك فقد تعذبت نفسه في الغربة فاكثف لله ما خفي عن بصيرته تلميذ حكيم، فبارك لي فيه

تسود المشاعر الدينية القصيدة من بدايتها، وتأتي ممثزجة بتوسلات الثـاعر لربـه أن يفرج عنه كُرب الغربة وآلامها، وبعد النداء يأتي حديثه عن نفسه بصيغة الغائب، فكأنه يتحدث عن شخص آخر يراه معذباً متوجعاً، إلى أن ينتهي كالمعتاد بالدعاء لتلميذه. (ز) أما كتاب (שפה ברורה: لغة واضحة) فهو مما ألفه ابن عزرا في قواعد اللغة

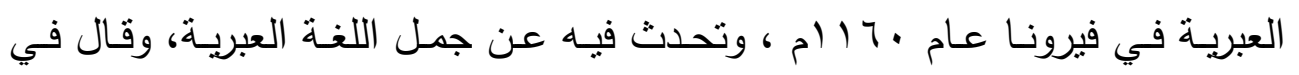


مقدمته أنه ألف هذا الكتاب تلبيةً لرغبة أحد تلاميذه ويدعى الربي شلومو، وأنه قصد

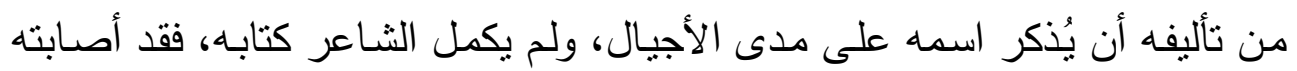

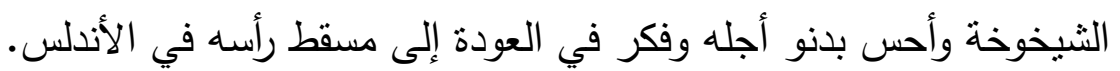

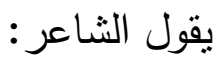

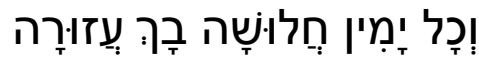

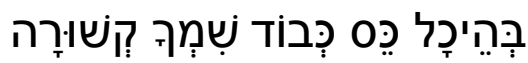

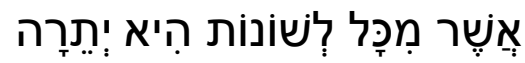

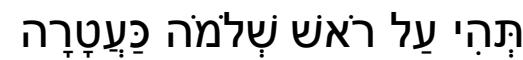

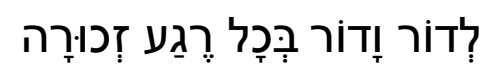

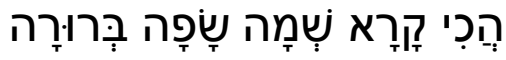

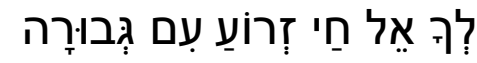

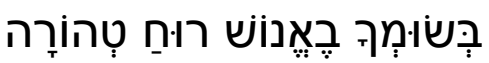

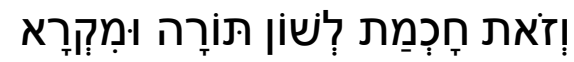

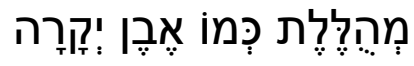

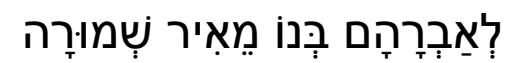

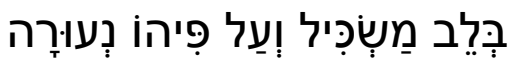

$$
\text { للك أيها الرب الحي القوة والبطش و أنت سند لكل ضعيف }
$$
لأنك وضعت في الإنسان روحا طاهرة و واسمك مرتبط بالهيكل وكرسي العرش الترن

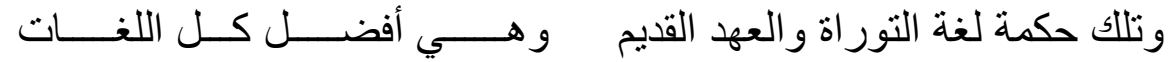

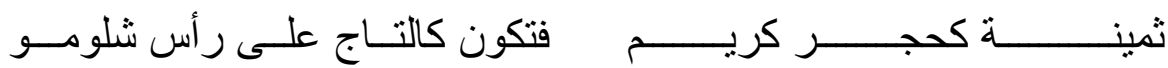

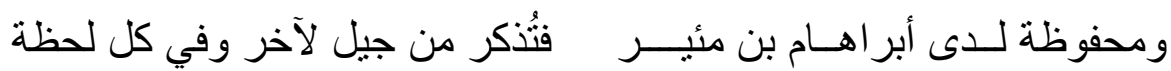

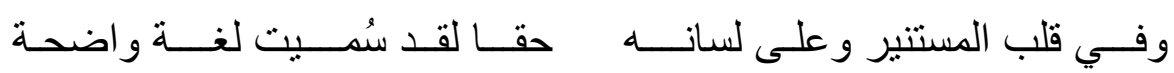
البيتان الأول والثاني من القصيدة مناجاة من الثـاعر لربه، بلغة يملؤها الإيمان بالله ذي القوة والبطش، الذي هو سند لكل ضعيف ومقهور، ثم بستوفي مدح اللغة

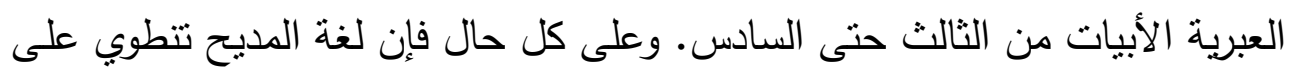
قدر من المبالغة، وبخاصة في الثطرة الثانية من البيت الثالث والبيت الرابع، فتضع

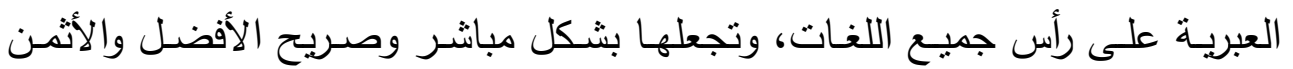
والأوضح. 
وكالمعتاد في كثير من أشعار هذا الرجل هناك بعض المعاني التي يلفها الغدوض كقوله في البيت الخامس (ومحفوظـة لدى أبراهام بـن مئير)، إذ كيف لـه أن يحفظ اللغة، وقد تكون الغاية أن الكتاب المهدى من الثاعر سيساهم في نشرها وتخليدها. ثنانيا: أشعار مهداة إلى حكماء:

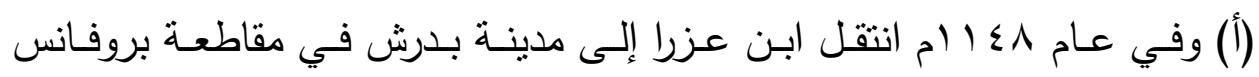
بجنوب فرنسا وكانت هذه المدينـة موطن الحكماء وفقهاء الثريعة اليهودية في تلك الفترة، وقد استقبله فيها الربي أبراهام بن حاييم والربي يتسحاق بن يهودا وأحسنا إلبه، فرد لهما الثـاعر الجميل بأن نظم المقطوعة التالية تكريماً لهما واعترافاً بفضلهما. وأهداهما أحد أهم مؤلفاته وهو كتاب (00 השه كتاب الاسم)، الذي كتبه بخط

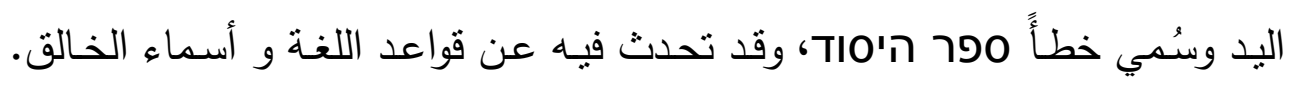
وكعادته في كثير من قصائد هذا القسم استهل ابن عزرا أبياته بالثتاء على المولى تبارك وتعالى، حيث قال:

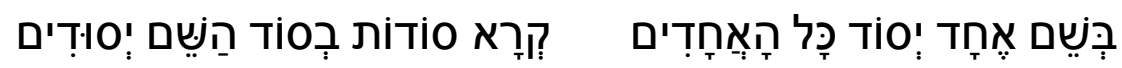

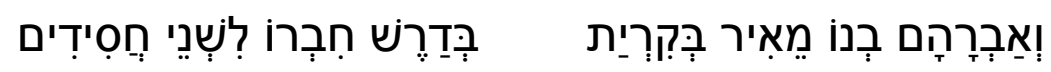

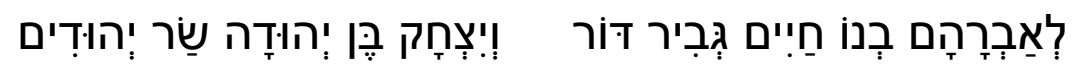

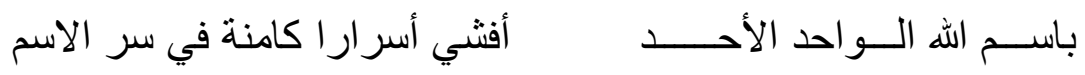

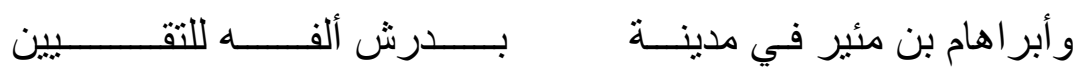

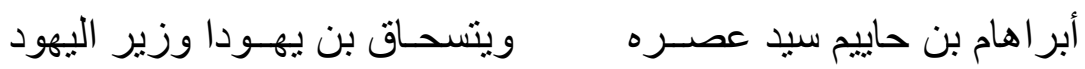
(ب) وفي عام •ـ إم رحل ابن عزرا إلى إيطاليا، وطاف بعدة مدن حتى استقر

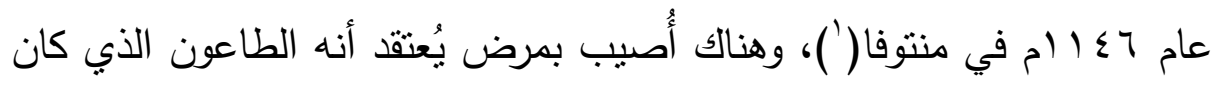
منتشراً نتيجة الحروب التي شهدتها البلاد في تلك الفترة، وساءت حالته الصحية 
ولم يلازمه طوال فترة مرضه سوى موشي بن مئير، أحد زعماء التصوف

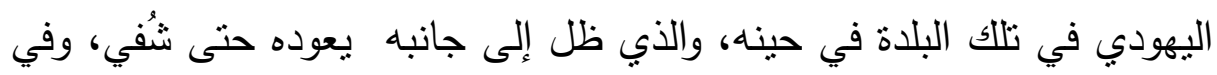

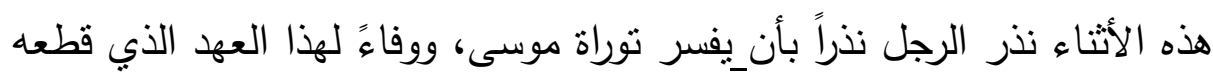

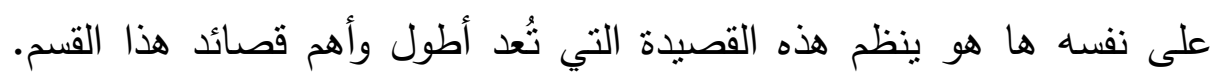
حيث قال: على نفيه

וְלְמְעוֹנוֹת שְׁחָקִים הוּא מְעוֹנָה

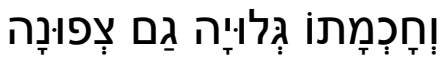

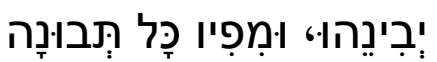

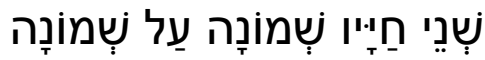

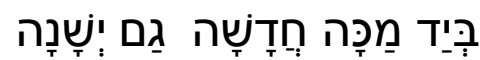

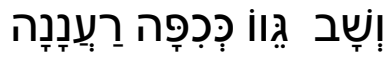
לִבְאָר דָדת דְּהַר

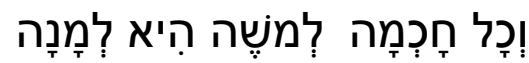

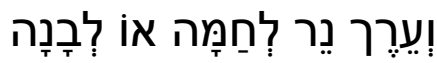

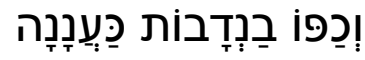

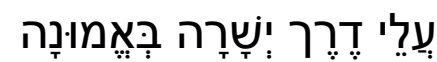

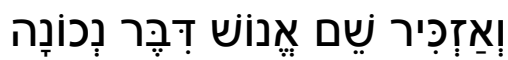

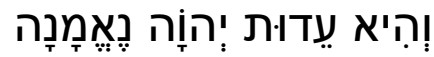

$$
\begin{aligned}
& \text { تبارك الله الذي ليس كمنله شيء وعرشه في أعلى عليين } \\
& \text { وحكمته ظاهرة وباطنة } \\
& \text { يُفهمه فينطق بكل الحكم } \\
& \text { في السادسة عشـرة. } \\
& \text { وتعالى فلا يراه أحد }
\end{aligned}
$$

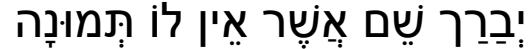

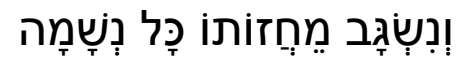

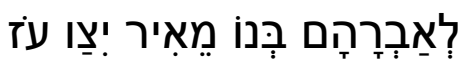

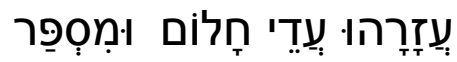

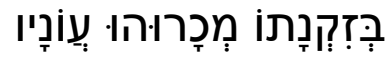

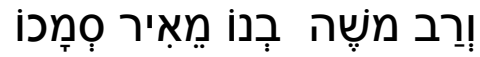

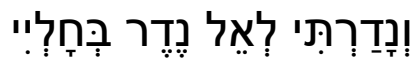

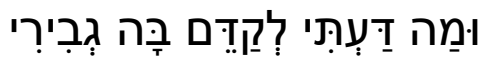

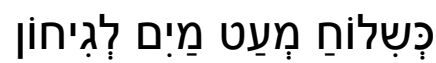

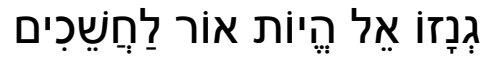

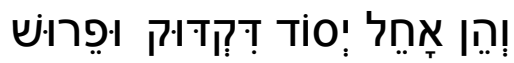

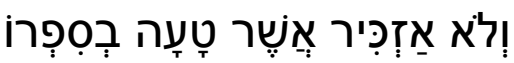

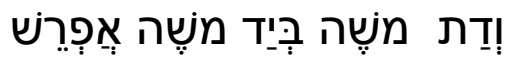


أن هذا المرض ربما أصابه في وقت سابق. أو أنه كان يظهر على فترات على شكل نوبات من الوباء.

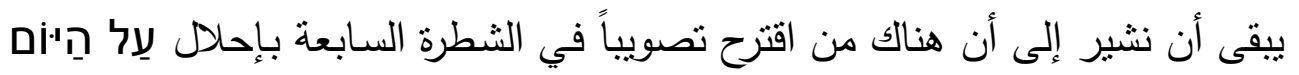

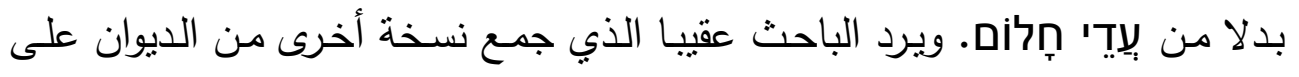

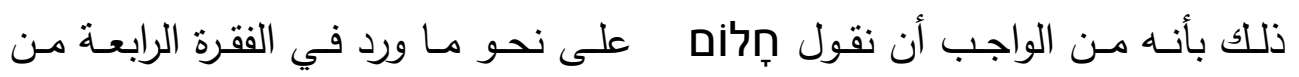

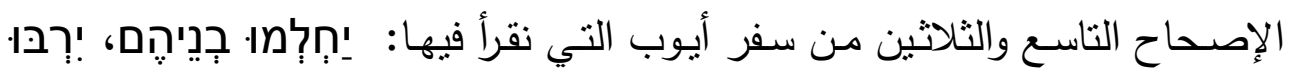

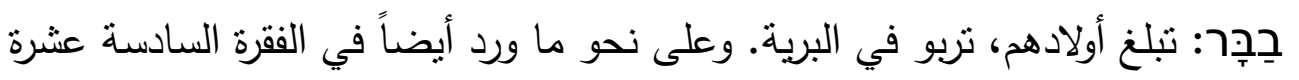

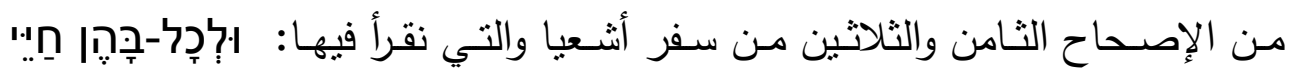

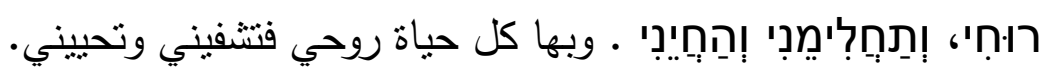
(ج) لما انتقل الثاعر إلى لندن وجد هناك ولي نعمته يوسف بن يعقوب الذي ألف

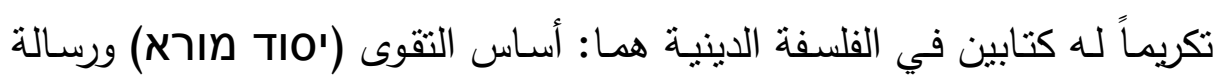

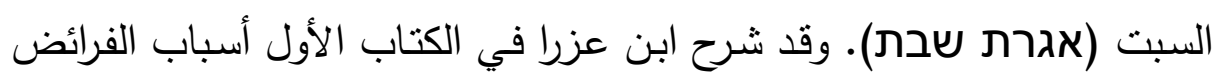

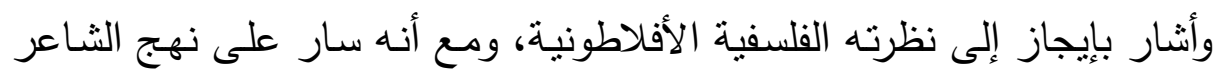

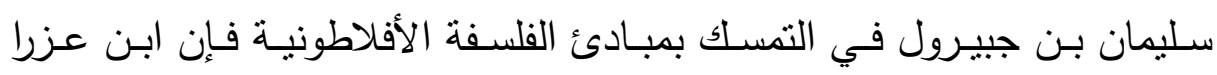

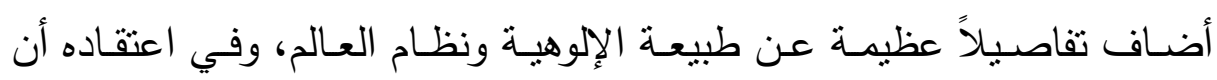

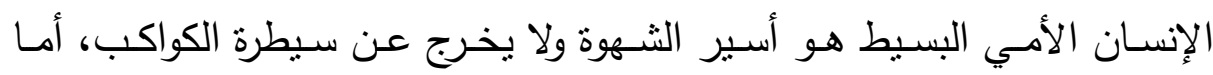

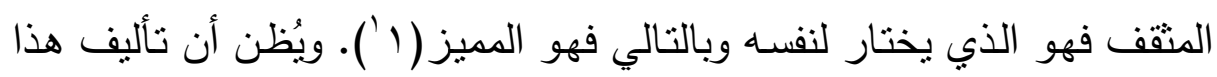

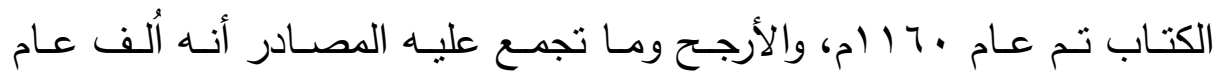
1101

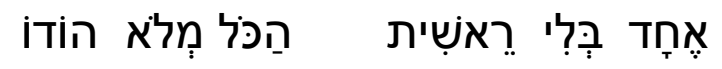

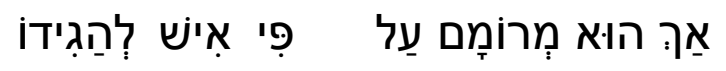




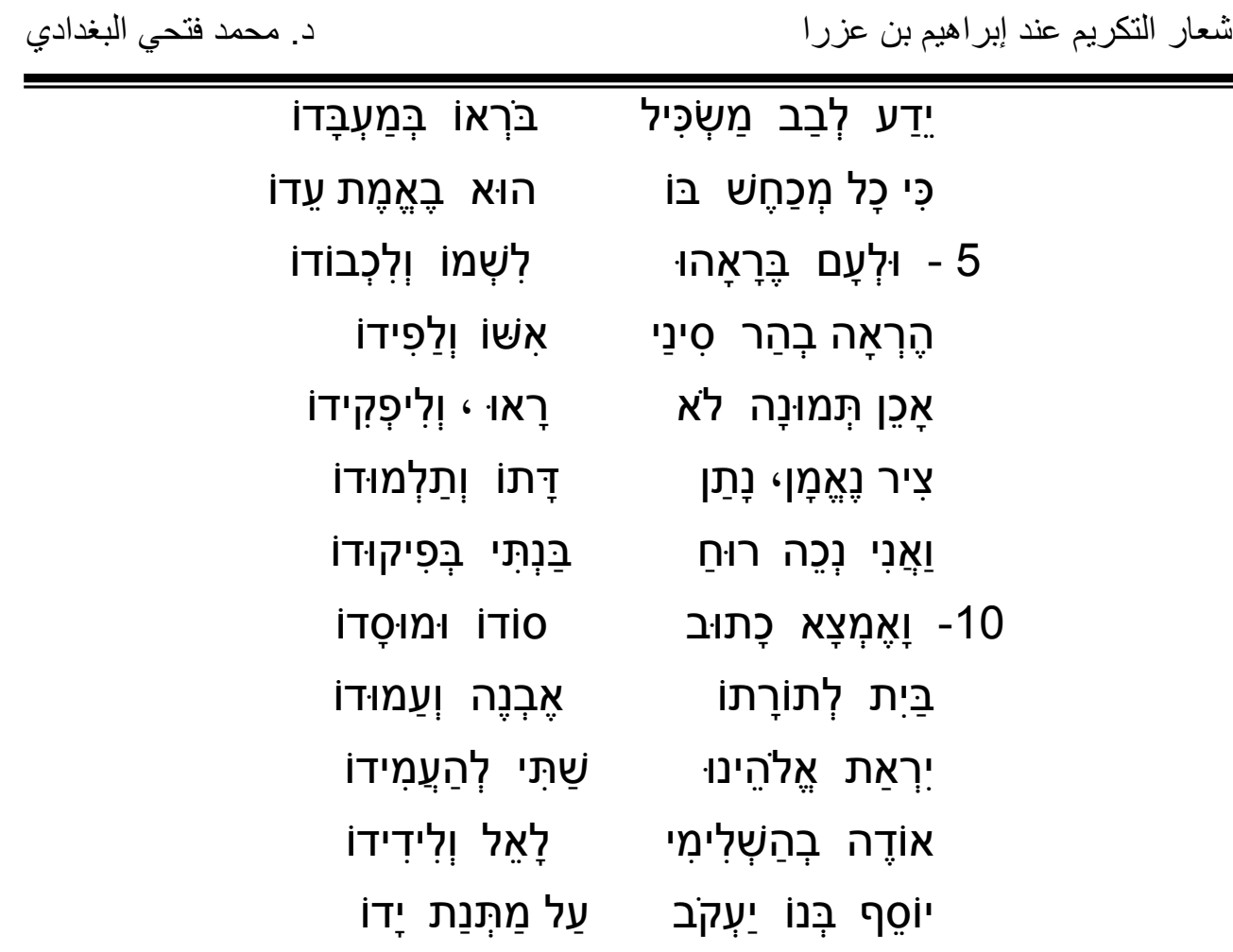

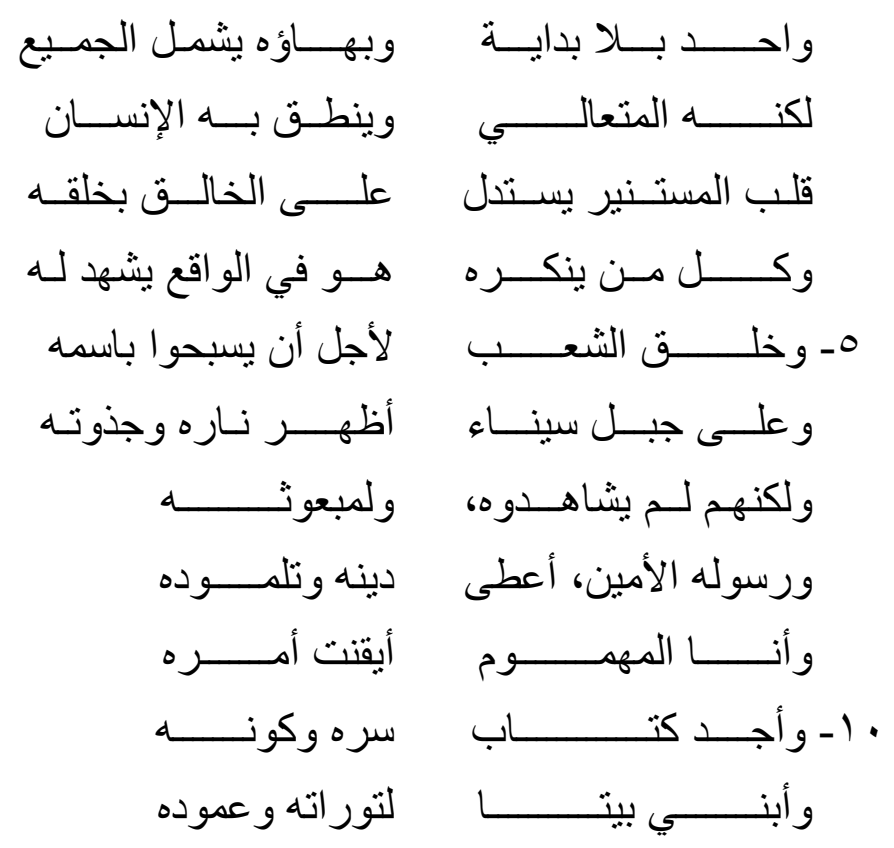

$\Lambda \cdot V$ 


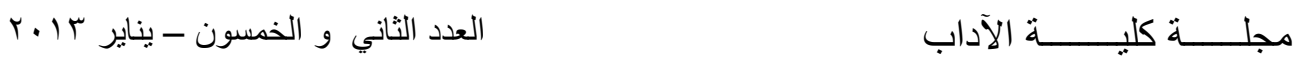

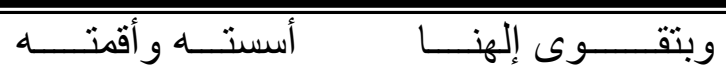

$$
\begin{aligned}
& \text { وأحمـــــ الله علـــى تمامه وكذا صديقي }
\end{aligned}
$$

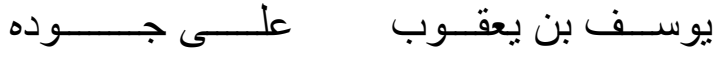

وهكذا نحن بصـد قصيدة صسيغت على نمط قصـائد التسبيح والتكبير الله سبحانه وتعالى، وقد امتزجت فيها مشاعر متباينة، مستمدة من الفلسفة والتصوف حيناً، ومن العقيدة اليهودية والتاريخ اليهودي حيناً آخر . وكما أن الصنعة تدل على الصـانع فإن المخلوق يبرهن على وجود الخالق، وغايـة الخلق أن يعبدوا ربهم ولا يشركوا بـه أحداً. وهنالك إثارة إلى ثوابت ورموز دينية كالتوراة والتلمود وجبل سيناء وسيدنا موسى عليه السام. ويسترعي انتباهنا اعتبار الثـاعر أن التلمود كالتوراة منزل من الله على قلب سيدنا موسى.

وكالمعتاد لا ينسـى الثـاعر معاناته وهمومسه، فهو دائم الثـكوى يترقب الفـرج، وينتظر عون الآخرين وعطفهم. ثم يحمد ربه أن قيض له يوسف بن يعقوب كي يحنو عليه ويجزل له العطاء. والمدهش بحق تلك الروح الإيمانية التي تسود معظم قصائد هذا القسم، رغم الآم الغربـة و مـرارة الفقر • والمـده أيضـاً ختم الثـاعر قصـائده بإبـداء الحمـد والرضـا والاعاء لمن أهدى له القصيدة، سواء كان حكيماً أو تلميذاً.

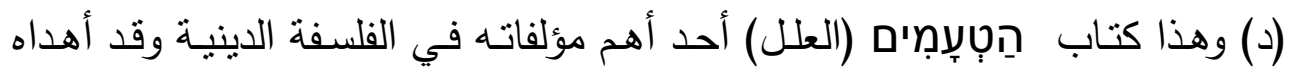
الثاعر للربي يوحنان بن دفيد، حيث قال:

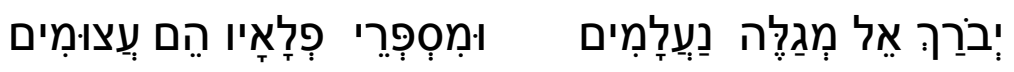

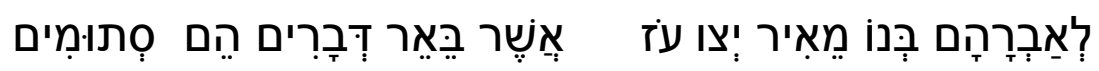

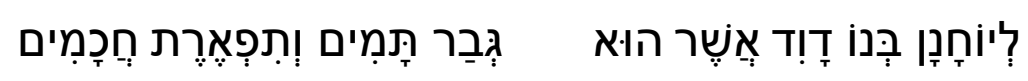

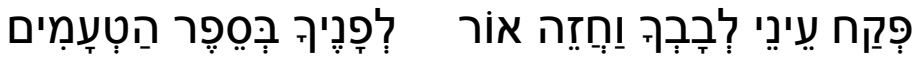




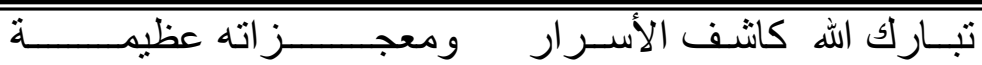
لأبر اهام بن منير بأمـر الجبار الذي فسر أنثياءً كانت غامضةً

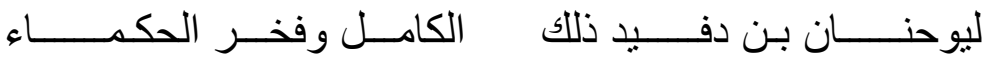

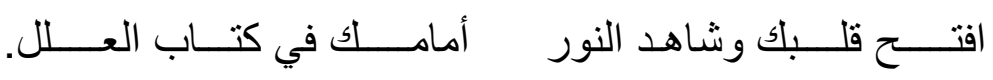
اسـتهل الثـاعر هذه الأبيـات كعادتهـ استهلالاً دينيـاً يكثـف قدرة المـولى تبـارك وتعالى على كثف أسرار كونه لمن يشاء من عباده، ثم انتقل بعدها إلى الحديث عن نفسه وعن كتابه والربي يوحنان الحكيم.

ولاثـيء يلفت الانتباه في هذه القصيدة أكثر مـن فخر الثـاعر بنفسـه وبصديقه وبكتابه، فهو المفسر وصديقة الحكيم، وكتابه نور ولا شيء آخر.

حتى العاطفة الدينية فيها ليست على نفس الدرجة التي في غيرها من القصائد.

$$
\text { أللغة والأسلوب: }
$$

لغـة ابن عزرا في مجملها نقيـة، تمزج بين الوضوح والفصاحة والبعد عن التعقيدات

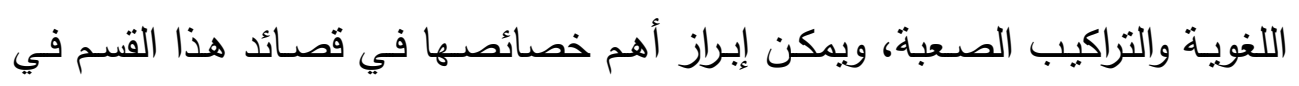

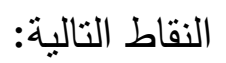
| - | - اعتزاز الثاعر بنفسه: فقصائد هذا القسم تفضح حب الثاعر لنفسه واعتزازه بها، فلا تكاد تخلو قصيدة من ذكر اسمه، كقوله في القصيدة الأولى: חִבּِר جְנأ מِאִיר: (ألفه بن مئير)، وقوله في

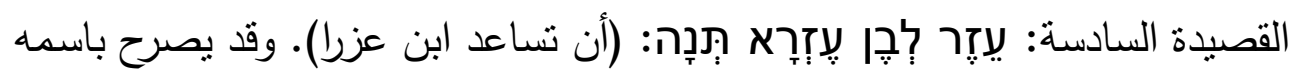

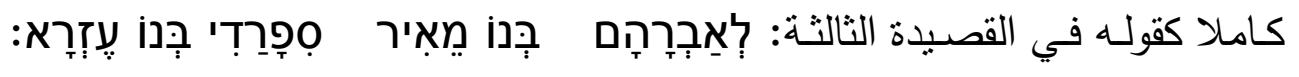




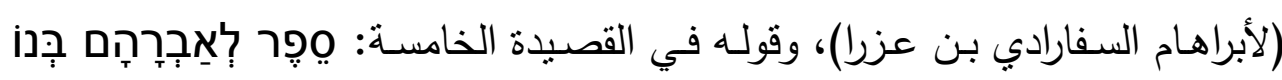

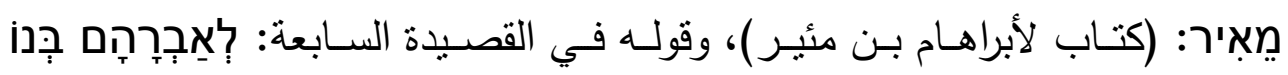

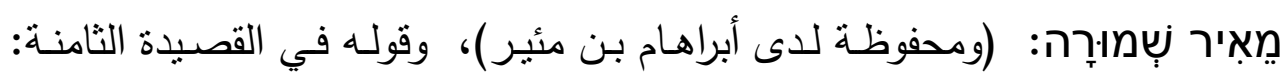

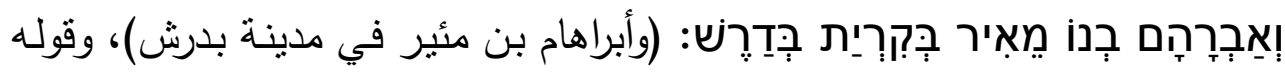

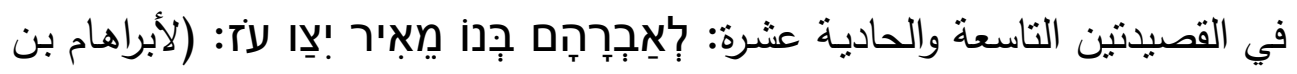
عزرا يأتمر بقوة). وتارة أخرى نجده يستخدم ضمير المتكلم كقوله في القصيدة الرابعة:

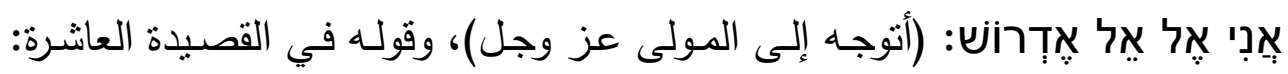

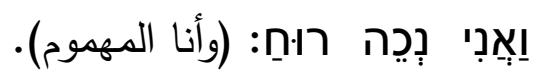

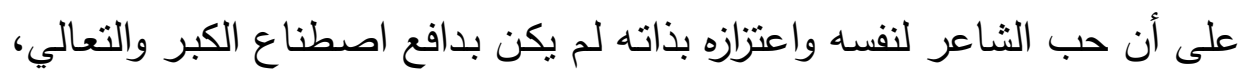
فنحن نقع على مواضع عدة تتفي عنه ذلك، وتثبت عدم تكلفه وميله إلى الاعتدال والتواضع، من ذلك قوله في القصيدة السادسة:

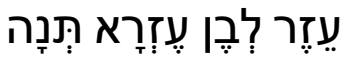

$$
\begin{aligned}
& \text { אֵל חַי לִּך אֶתְחַבְנָנה }
\end{aligned}
$$

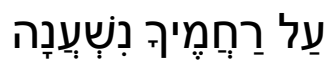

$$
\begin{aligned}
& \text { נַפְשׁוֹ בְגָלוּוּת נַעְנָּה } \\
& \text { أن نساعد ابن عزرا } \\
& \text { الهي أنوسل إليك } \\
& \text { واعتمدت على رحماتك } \\
& \text { فقد تعذبت نفسه في الغربة }
\end{aligned}
$$

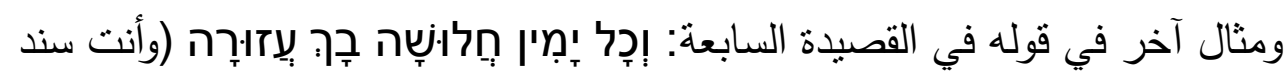
لكل ضعيف). Y - خصوصية استخدام بعض المفردات:

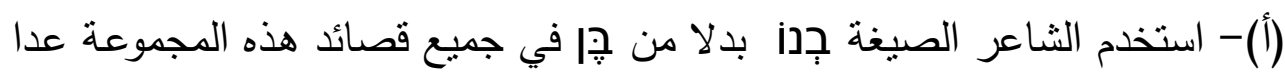
القصيدنين السادسة والثامنة، وهو استخدام لم نعهده عند من سبقوه من شعراء اليهود 
في الأندلس، ولا ندري سبباً واضحاً لذلك، وربما يكون هذا تأثراً بالصيغة العربية (بنو)

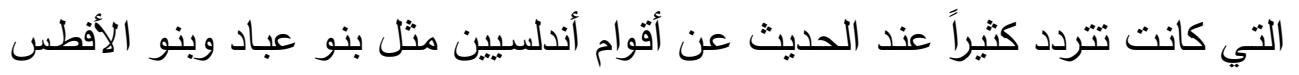
وبنو عامر وبنو صمادح وبنو هود وبنو زيري وغيرهم. ويرد هذا الاستخدام عندما

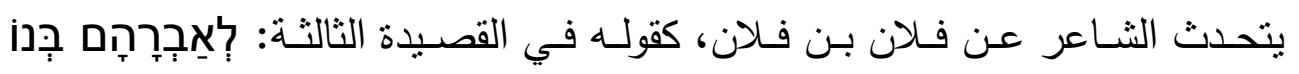

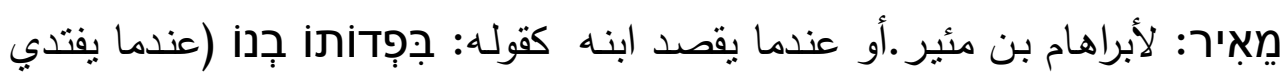

وكذلك إذا تحدث عن أحد باستخدام لقب العائلة فقط فكان يعدد إلى هذه الصيغة

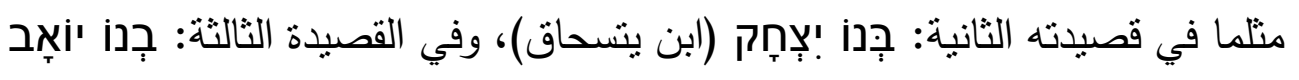

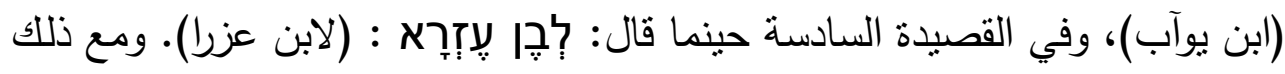

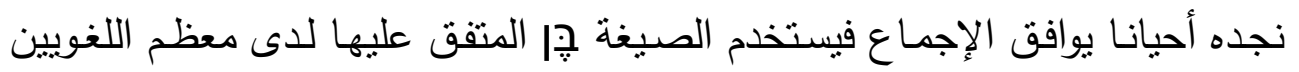
والأدباء اليهود، كقوله في القصيدة الثامنة:

\section{לְאַבְרָהָם בְנוֹ חַיים"}

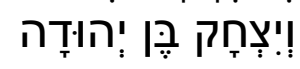

(ب) - وعلى غير المألوف أيضاً لدى سابقيه من الثعراء اليهود استخدم الثاعر لفظ :مإِה الثنائع في العهد القديم للالالة على الذات الإلهية، فقال في القصيدة التاسعة:

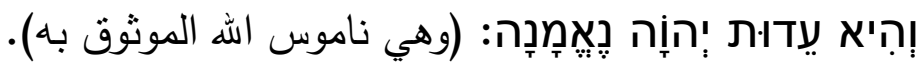

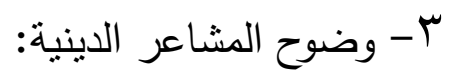
تزخر القصائد الثالثة والرابعة والسادسة والسابعة والثامنة والتناسعة والعاشرة والحادية

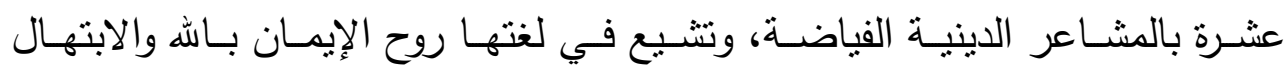

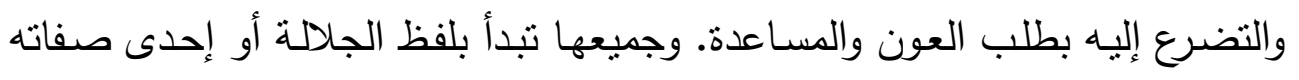

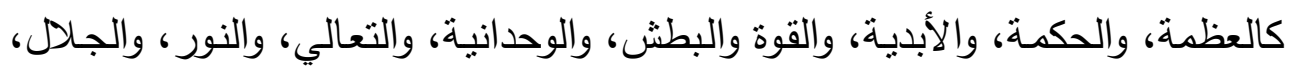

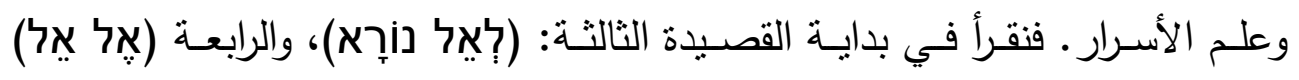




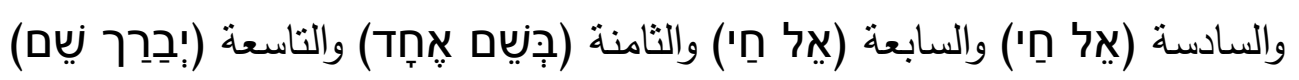

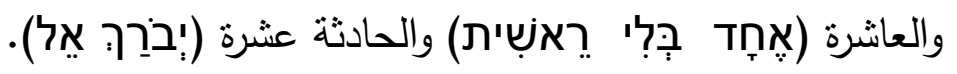
وتتفرد القصيدة السادسـة التي خصصـها الثـاعر لإهداء كتابـه عن الإسطرلاب

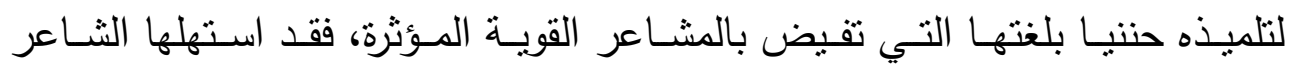

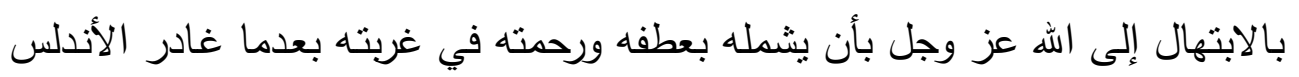

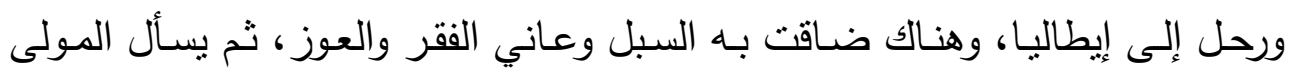

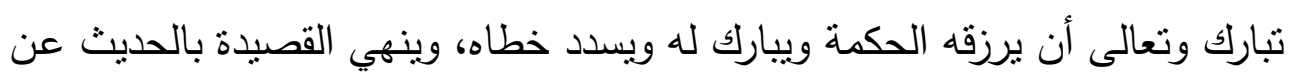
تلميذه ويدعو له بالبركة ويتمنى أن بسعد بها.

ثم لا يجد ابن عزرا في نفسه حرجاً في أن ينتقد جهرة بعض الحكماء اليهود ممن

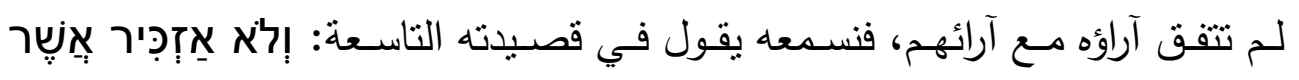

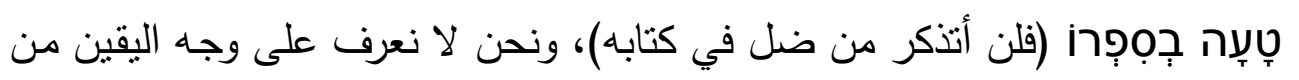

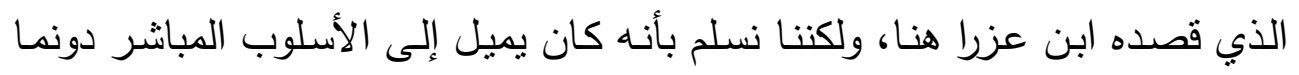

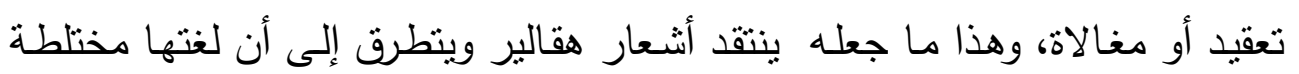
بلغة التلمود وأن بعض كلماتها مشوشة وبعيدة عن قواعد اللغة.

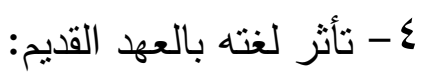
لغة ابن عزرا شأنها شأن لغة سائر الثـعراء اليهود في الأندلس من لدن دوناش بن

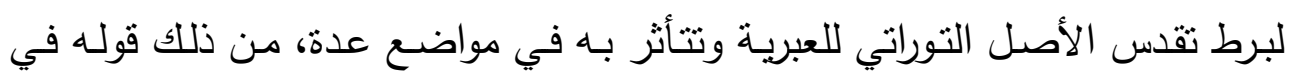

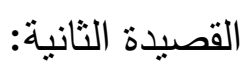

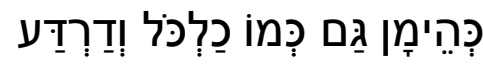

كهيمان وأيضاً منل كلكول ودردع

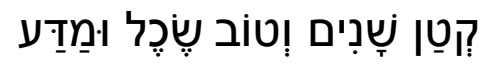
صغير السن ذو عقل وعلم وتجدر الإثـارة إلى أن الأسماء المذكورة في الثطرة الثانية من البيت الثاني مأخوذة من الفقرة الحادية عشرة من الإصحاح الخامس من سفر الملوك الأول التي نقرأ فيها: 


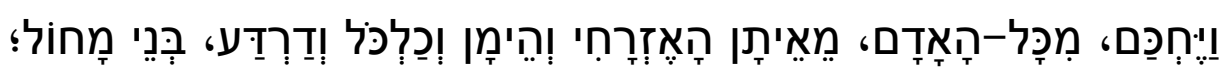

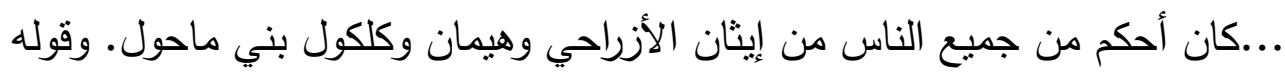

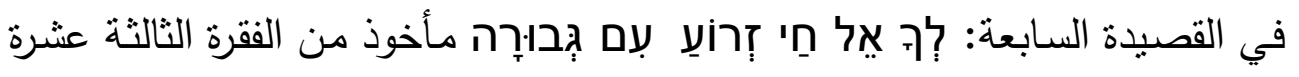

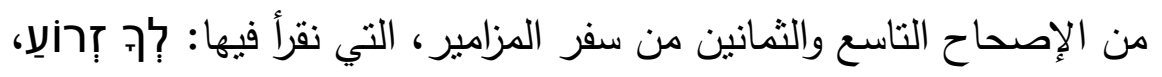

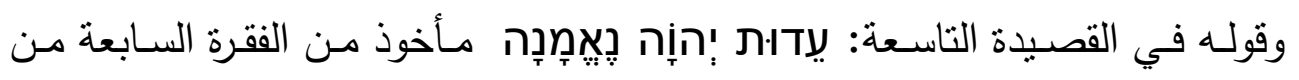

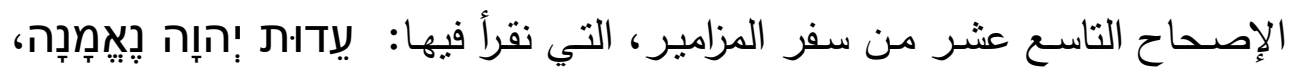

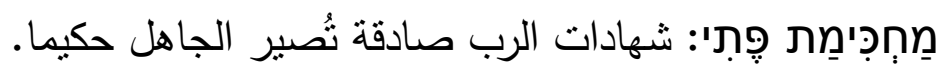
0- استخدام الثناعر بعض الصيخ الرياضية:

ولدى ابن عزرا مهارة خاصة وميول واضحة في مجال الرياضيات، ونجده في بعض

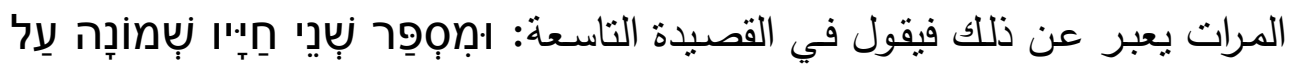

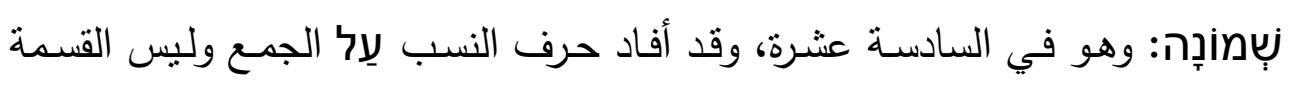

$$
\begin{aligned}
& \text { كما هو متعارف عليه في العربية. } \\
& \text { ثنانيا: الأسلوب }
\end{aligned}
$$

يتسم أسلوب ابن عزرا في مجمله بالواقعية، مـع ميل إلى استخدام الجمل القصيرة

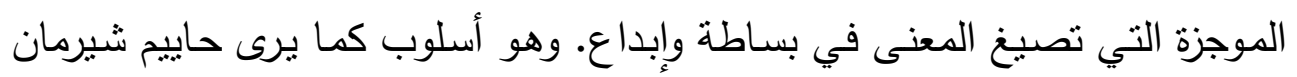

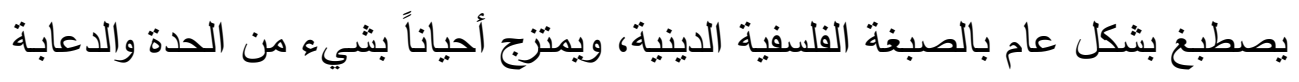

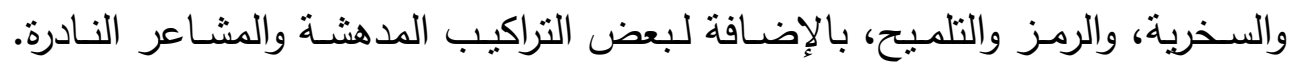

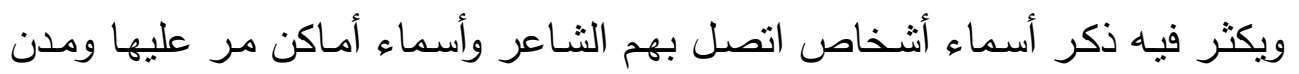

$$
\text { طاف بها ('). (') }
$$

דביר ת"א, ירושלים , מוסד ביאליק, חיים שירמן: השירה העברית בספרד ובפרובאנס $1955-1961$

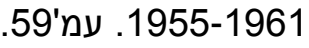


(1)- هذا و تتتوع أساليب ابن عزرا في هذه المجموعة من القصائد، فمن الأساليب البلاغية التقديم و التأخير ، حينما قال:

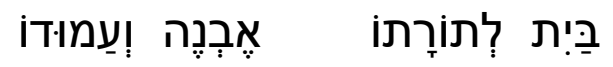

$$
\text { وأبني بيتا لتوراته وعموده }
$$

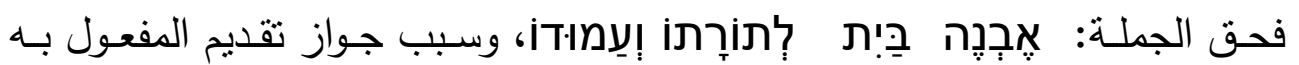
على الفعل هو حرص الثاعر على استقامة الوزن.

(Y)- ونقع على مواضع اصطنع فيها الثـاعر أسلوب النداء وسيلة ليتضرع إلى ربــ ويناجيه، يسأله الرحمة والعون والسداد، كقوله في القصيدة السادسة:

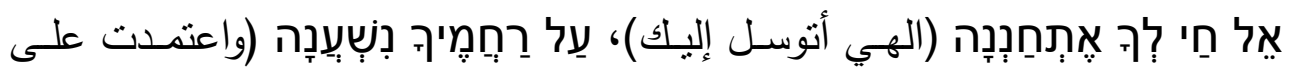

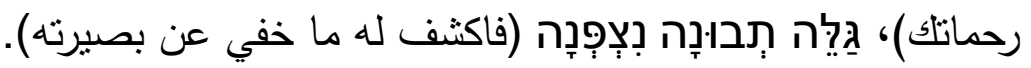
وقوله في القصبدة السابعة: לִךך אַל חַי זְרוֹעַ עִם בְבבוּרָה

للك أيها الرب الحي القوة والبطش وأنت سند لكل ضعيف (r) - ومن أساليب الاستقهام قوله في القصيدة التاسعة:

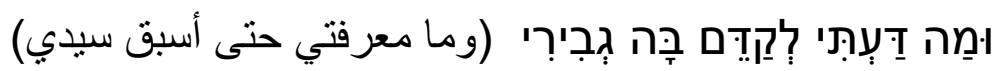
وهو استفهام غرضه التواضع، ومجاملة الربي موشي بإدعاء الثـاعر بأنه أغزر منه أغها علماً وأكثر منه فقهاً. (ع)- التكرار بغرض التأكيد: ويكون في الألفاظ دون المعاني، ولا يقصد التكرار لذاته وإنما لما يضيفه إلى المعنى، وما يحدثه من إيقاع حسن وأثر موسيقي طيب. ومن ون مواضع التكرار قوله في القصيدة الثالثة:

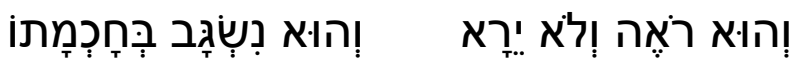




$$
\text { إنـه يرانا ولا نراه وهو الجليل بحكمته }
$$

(0)- حسن التقيم: الذي عرفه أبو هلال العسكري بأنه تقسيم الكلام قسمة مستوية تحتوى على جميع أنواعه ولا يخرج منها جنس من أجناسـ('). وأثنار إليه موسى بن بن عزرا في معرض حديثه عن محاسن الثـعر في الفصل الخامس من كتابه الثـهير "المحاضـرة والمذاكرة" فقال: وغرض هذا هذا البـاب أن يفسر الثـاعر مـا ابتدأ بـه، فـلا

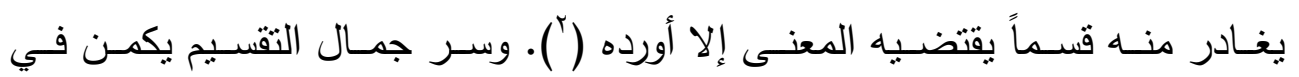
الموسيقى ذات الإيقاع الجميل التي يكتسبها الثـعر بـه. ومن أمثلته في قصائد هذا القسم من شعر ابن عزرا قوله في القصيدة الثالثة:

וְהוּא רָאֶה וְלא יִירא

إنه برانا ولا نراه

$$
\text { חְּננוּ כָבוֹד לְאֵל נוֹרָא }
$$$$
\text { مجدوا المولى العظيم }
$$

وقوله في القصيدة العاشرة:

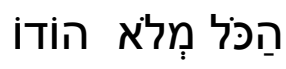

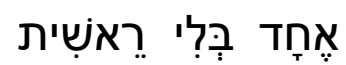

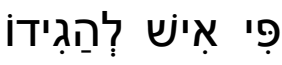

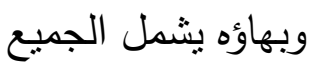

وبنطق بـه الإنسان

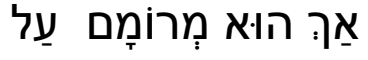

$$
\text { واحد بلا بدايـة }
$$

لكنه المتعالـي

' أبو هلال العسكري: الصناعتين: الكتابة والثعر ، تحقيق على محمد البجاوي ومحمد أبي الفضل إبراهيم،

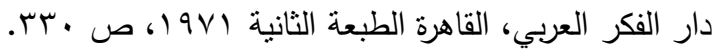

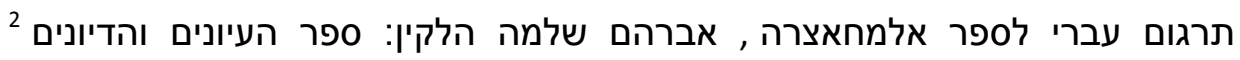
ירושלים 1975. עמ' 242., מקיצי נרדמים ,לר' משה בן יעקב אבן עזרא ,ואל מדאכרה 
(7)- أما الحوار الذي يُعد أحد أبرز سمات أسلوب ابن عزرا بصفة عامة حتى قيل

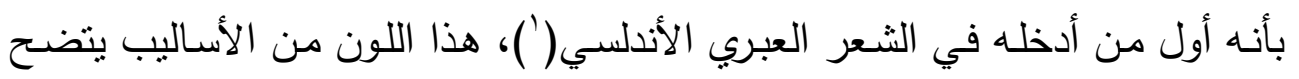

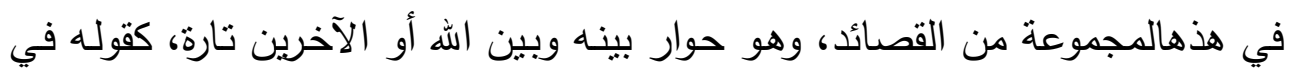
القصبدة السادسة:

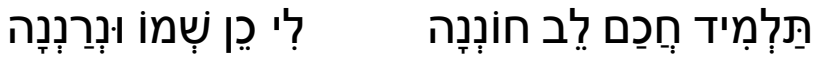

$$
\begin{aligned}
& \text { تلميذ حكيم، فبارك لي فيه وأسعدني به كاسمه. }
\end{aligned}
$$

أو هو حوار داخلي يدور بين الثاعر ونفسه تارة أخرى، كقوله في القصيدة التاسعة:

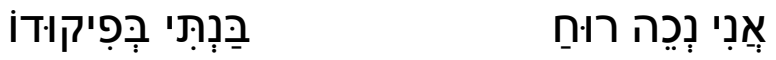

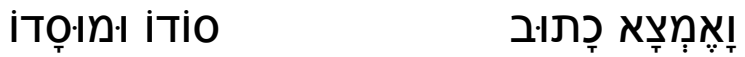

$$
\begin{aligned}
& \text { وأنا المهموم }
\end{aligned}
$$

(V) يبقى أن نشير إلى أن ما أنشاعته المصـادر العبريـة وردده باحثونـا العرب من

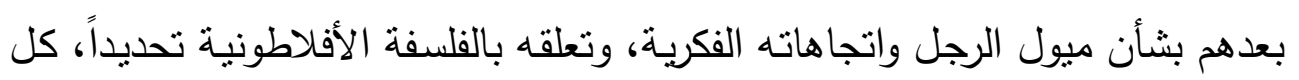

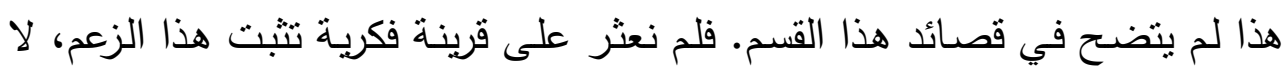

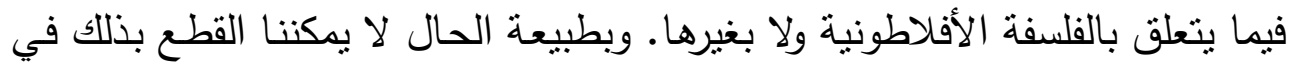
باقي فنون وأغراض شعرة.

الصور و المحسنات 
قصائد هذا القسم تضع إبراهيم بن عزرا في مصاف الثـعراء الذين لا يولون عناية خاصة بالصور البيانية والمحسنات البديعية في أثنعارهم، فهو إذاً من شعراء الطبقة

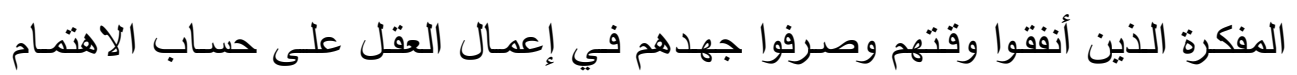

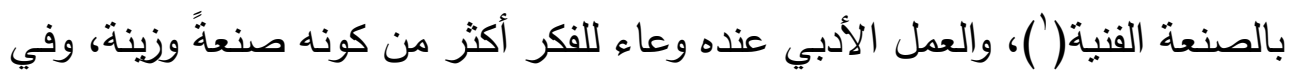
هذا السياق تحدث عنه الباحث إسرائيل لفين فقال:

مال ابن عزرا في أثشعاره إلى قلة المحسنات، وتخلى عن الجماليات المتحذلقة التي

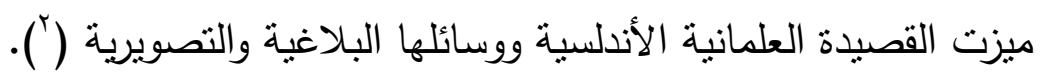
ويأتي التشبيه والاستعارة في مقدمة الأجناس البيانية التي توسل بها الثاعر في رسم لوحاته الفنية في قصائد هذا القسم، وهو في هذا مع غالبية شعراء اليهود الأندلسيين

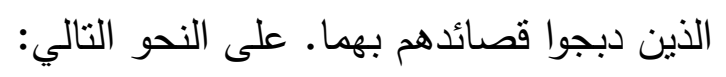
أولا: الصور البيانية:

1 - التشبيه: وهو أحد الفصول الهامة في علم البيان، ومن أعظمها شأناً، وأوضحها

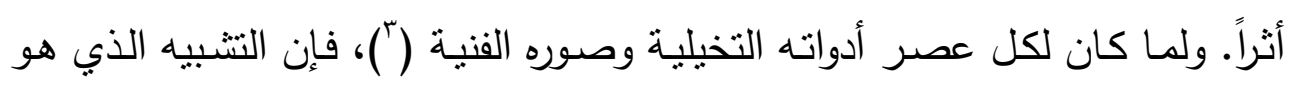

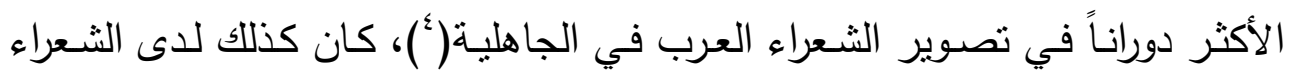

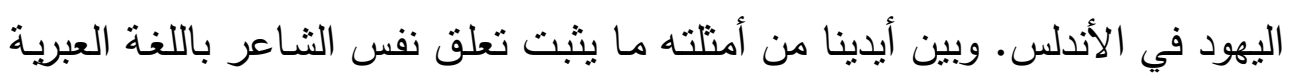

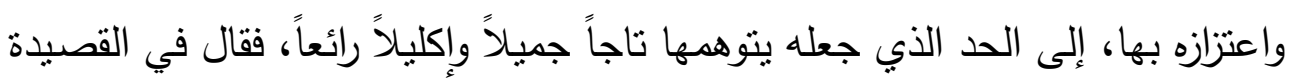

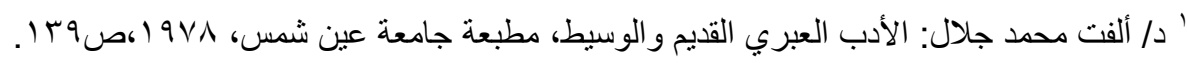

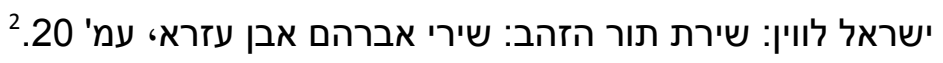

${ }^{3}$ Rene Wellek and Austin Warren: theory of literature. London.1949,p 137.

؛ د د محمود فهمي حجازي ود/ النعمان القاضي: العربية- نصوص ودر اسات، مطبعة كلير كوبي، القاهرة . . 


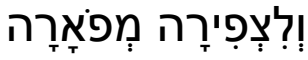

$$
\begin{aligned}
& \text { הֶיוֹתוֹ בְעִטֶרֶת הוֹד } \\
& \text { عن جعله تاجاً جميلاً إكليلاً رائعاً }
\end{aligned}
$$

ثم مـا انفلك ابـن عزرا في موضـع آخـر يُعلى مـن شـأنها ويجعلهـا ثمينـة ونفيسـة كالأحجـار الكريمـة، ويمانلهـا بالتـاج الذي تـزدان بـه الـرؤوس. فيقول في القصيدة السابعة:

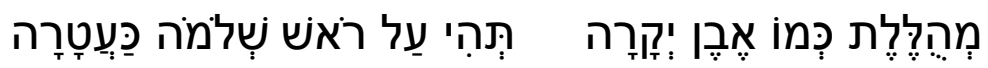

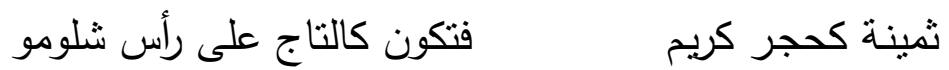

وها هو يعمد إلى تثبيه كتاب ألفه بالصابون، بالنظر إلى أثزه في تتظيف القلوب مما

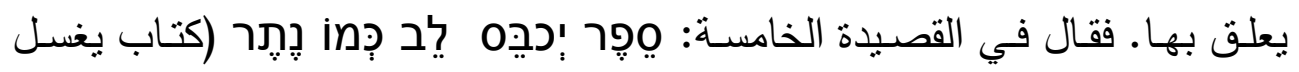
الفؤاد كالصابون)، حيث شبه أثز الكتاب بأثز الصابون، والمراد أن هذا الكتاب يُجلي العقيدة وينقي الفؤاد مـن الخبائتث والأدران. وفي القصيدة التاسـعة استعار الثـاعر

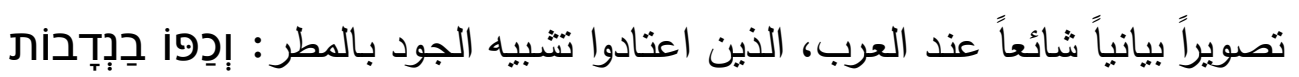

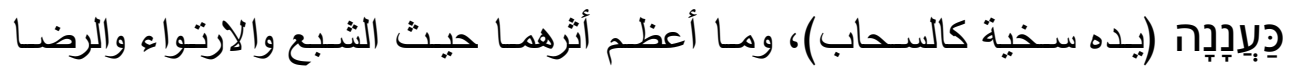
بالعطاء. ولما برئ إبراهيم بن عزرا من داء ألم بـه، واستعاد عافيته من جديد، شبه واءله ظهره الذي عاد إلى طبيعته و حيويته بالكربـة النضـرة، فقال في القصيدة التاسعة:

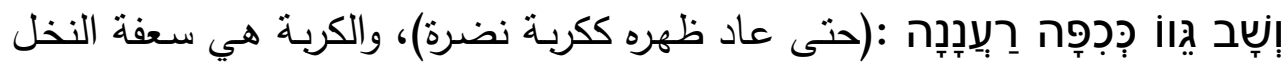

$$
\text { التي تبقى في الجذع. }
$$

ولا تكمن طرافة هذا التشبيه في الإتبان بمشبه بـه بعيد شيئاً ما عن الخاطر فقط، وإنما في وجه الثبه أيضاً، حيث استعادة الحياة بعد استحالتها.

وهكذا ومن خـلال استقرائنا للنمـاذج التي بين أيدينا يتبين لدينا أن شـاعرنا استساغ وارتاح في غالب الأحيان للمألوف من التشبيهات، وأنه لم يكد نفسه في البحث عن الجديد من صور التشبيه إلا في أضيق الحدود، فجاءت أغلب تشبيهاته من النوع الأصيل، بل والمبتذل أحياناً. بينما جاء بعضها فقط من النوع الجديد المبتكر. 
r- الاستعارة: وللاستعارة قدرها في تدبيج الثـعر ونزويق الصياغة وجلاء المعنى، وهي أفضل المجـاز إذا وقعت موقعها ونزلت منزلها. ولكنها تأتي في مرتبـة ناليـة للنتبيه من حيث إقبال عامة الثعراء اليهود في الأندلس عليها، وربما كان سبب ذلك أن التشبيه أبسط في بنائهه مـن الاستعارة، التي تحتاج بُعداً في الخيال وعمقاً في التصوير ('). والحق أن أمنلتها قليلة في قصائد هذا القسم من شعر إبراهيم بن عزرا.

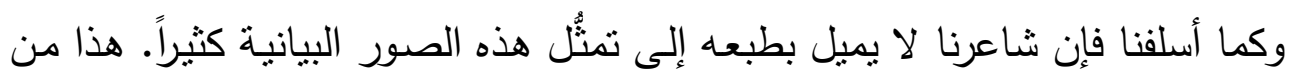
ناحية، ومن ناحية أخرى فإن موضوع القصائد ذاته لا يسمح بمجال أكبر للعاطفة والخيال.

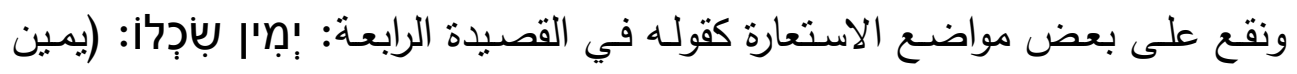
عقله)، فقد استعار للعقل يميناً.

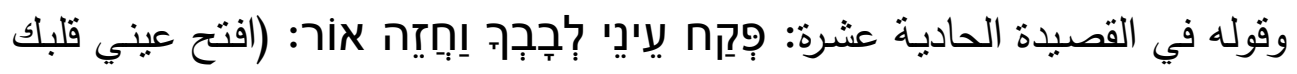
وشاهد النور)، وهنا استعارة مركبة حيث جسد القلب في صورة إنسان له عينان يرى له بهما، كما شبه كتابه العلل بالنور الذي بهدى. وعلى كل حال فإن مثل هذه الثواهد تُعد من باب الاستعارات الدارجة التي فقدت بريقها وصارت مبتذلة.

ولعل من أفضل استعارات ابن عزرا في هذه المجموعة من القصائد قوله في القصبدة الثالثة: بְבִינְיָמִין :יְליד חָجְמָה: (لبنيامين سليل الحكمة)، ويكمن سر جمال هذا التصوير البياني في التشخيص الذي جعل الحكمة وهي شيء معنوي كأنها امرأة

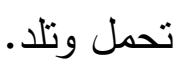


ب- المجـاز : وهو مما استحسنه نقاد الأدب، وعدوه من أفضل البيان، كقوله في

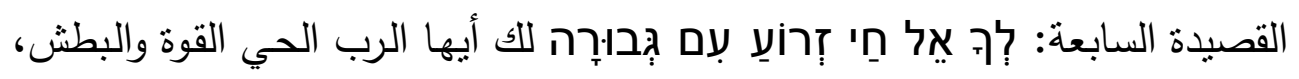

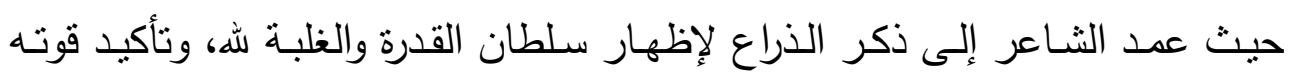

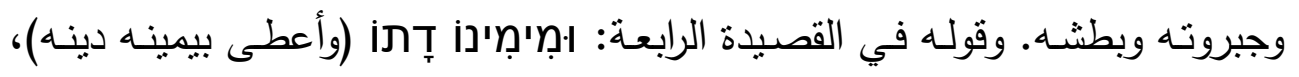

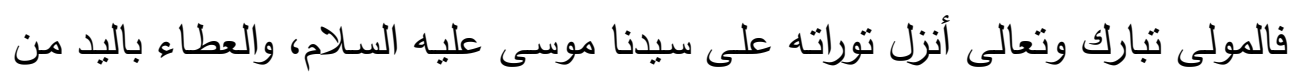
شيم البشر ولكن عطاء الربوبية له شأن آخر . ع - الكناية: والكناية كذللك من صور البيان التي استجادها الثُعراء ورغبوا في صوغ

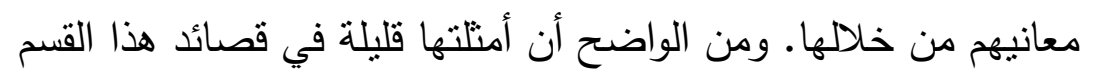

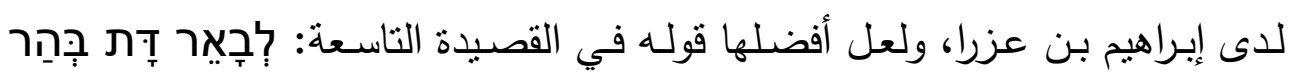

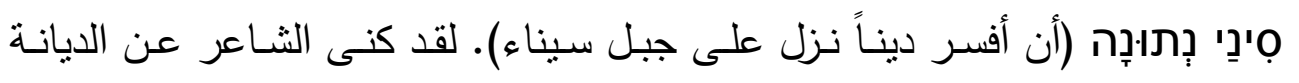
اليهودية، فهي من دون شك الديانة الوحيدة التي نزلت على جبل سيناء. ثنانياً: المحسنات البديعية:

للمحسنات البديعيـة شـأن واضـح في تتميـق الثـعر وتدبيجـه، وقد اثـترط النقاد

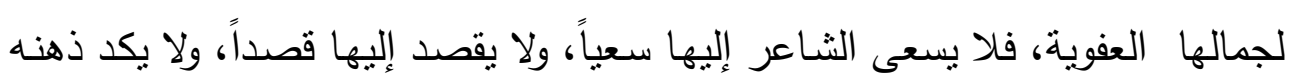

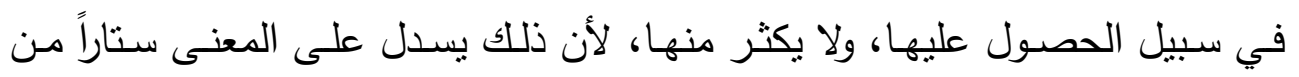

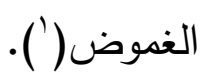

ويأتي الجناس في مقدمة محسنات هذا القسم من قصائد ابن عزرا، مما أضفى عليها

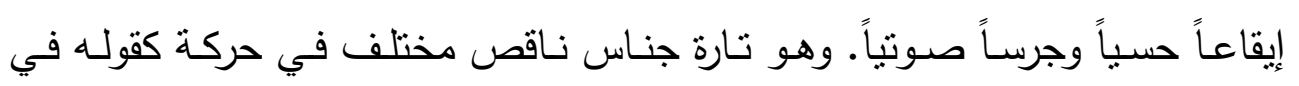


القصيدة الرابعـة: عِל אِל، فالكلمـة الأولى حرف نسب والثانيـة لفظ الجلالهـة. وتـارة أخرى نجده جناساً ناقصاً مختلفاً في أكثر من حركتين كقوله في القصيدة الثانية: :

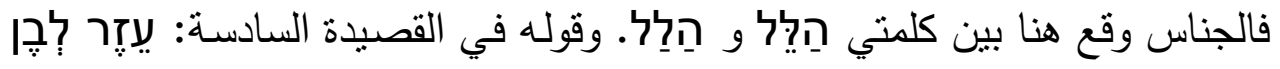

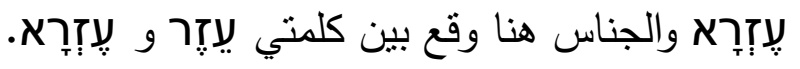

ووقع الجناس في بعض الأحيان بين أكثر من كلمتين كقوله في القصيدة الثامنة: קְרָא ناقص أيضاً.

التضـاد: ويسمى أيضاً الطباق، وهو يثبت المعنى ويوضحه، ولا قيمة للتضاد إذا كان مجرد كلمتين متضـادتين، وإنما قيمته فيما يثير في النص من مشـاعر قوية تكمل

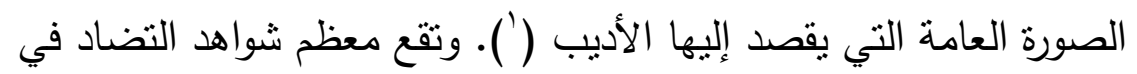

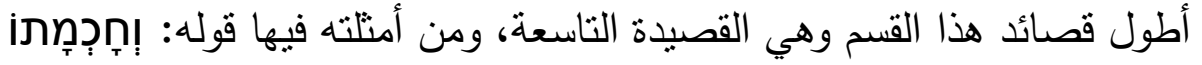

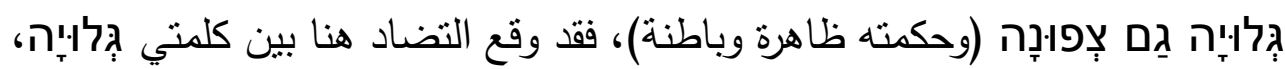

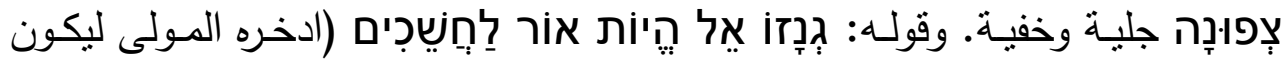

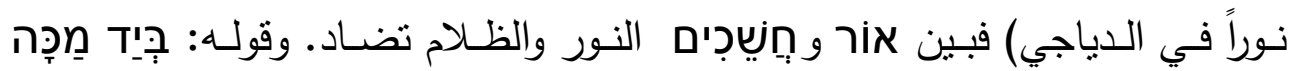

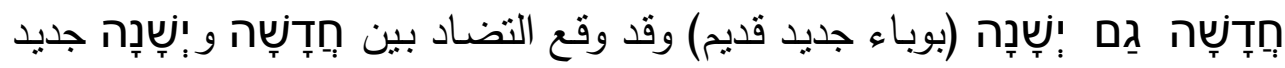

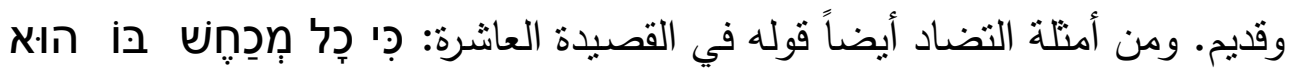

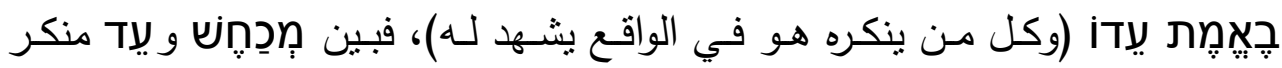
وشاهد تضاد. 
التر ادف: ويقصد به وقوع لفظتين بمعنى واحد أو متقاربتين فيه في جملة واحدة أو

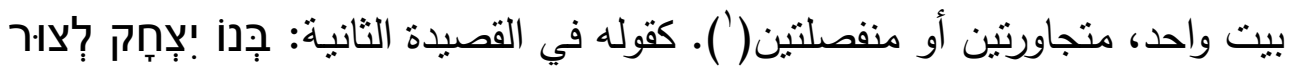

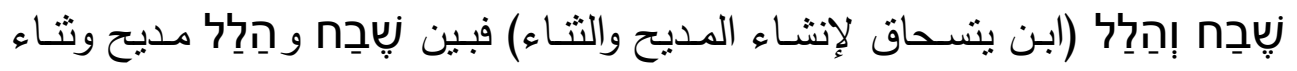
ترادف. وقد يبدو الجمع بين المترادفتين في القافية أحياناً محض وسيلة لإنهاء البيت لإنياء

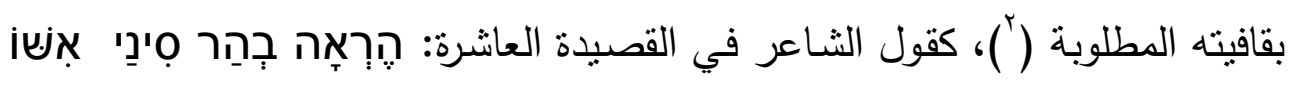

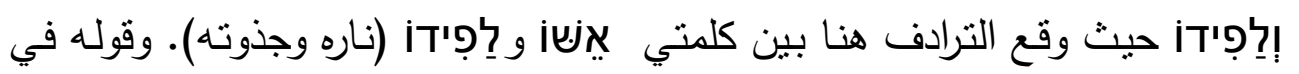

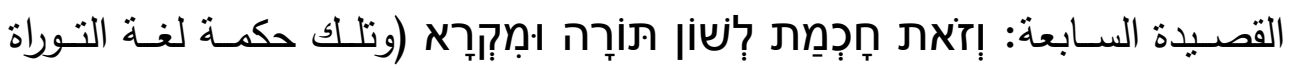
والعهد القديم)، فقد وقع الترادف هنا بين كلمتي هـּأרِה و מִקְרא (التوراة والمقرا). المبالغـة: وهي أن نبلغ بالثـيء أقصى غاياته، وأبعد نهاياته، ومن النقاد من يرى

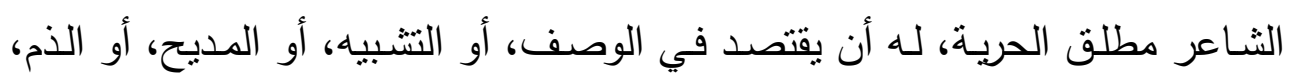
ولـه أن يبـالغ، ولـه أن يسـرف، حتى يناسـب قولـه المحسال ويضـاهيه، ولا يستحسـن السرف والكنب والإحالة في شيء من فنون القول إلا في الشعر .

وذكر أرسطاطاليس الشعر فوصفه بأن الكذب فيه أكثر من الصدق، وذكر أن ذلك جائز في الصناعة الشعرية("). ومن أمثلته كقول ابن عزرا في القصيدة التاسعة:

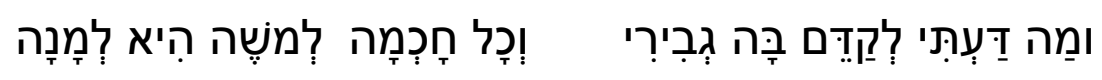

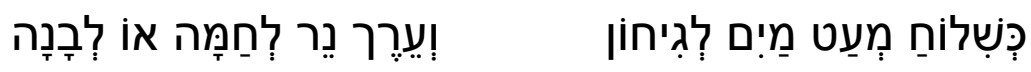
وما معرفتي حتى أسبق سيدي ولإن وكل حكمة هي من نصيب موشي

' دم/ محمد العبد: إيداع الدلالة في الثعر الجاهلي، مدخل لغوي أسلوبي، دار المعارف، الطبعة الأولى، 911 ا، صט

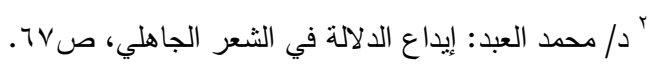

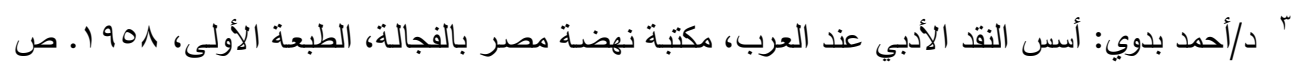
.. .9 
كإرسال قليل من الماء إلى جيحون وكقيمة الثمعة بالنسبة للثمس أو القمر ففي

سياق مدح الثـاعر لصديقه موشي بن مئير الذي عاده في مرضـه حتى شُفي نراه يتمـادى ويغالى حينما يقصر الحكمة على شخص بن مئير دون سواه. نعم الحكمة كلها من نصيبه، وقد اختص بها وحده، ليس هذا وحسب بل إن الثـاعر يغالى في رفع قدر صاحبه، فأين هو منه، إنه كقليل الماء بالمقارنة بنهر جيحون، وهو بالنسبة له كالثمعة أمام الثمس أو القمر . الترصيع: وهو أن يتوخى الثـاعر تقطيع أجزاء البيت على سجع أو شبيه بـه أو من جنس واحد في التصريف، وسر جماله أنه يزيد موسيقى الثعر جمالاً، واشترط قدامة بن جعفر لجمال الترصيع ألا يأتي متكلفاً، وأن يتفق له في البيت موضـع يليق بـه، لأنه ليس في كل موضع يحسن('). ومن أفضل الترصيع قول ابن عزرا في القصيدة

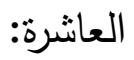

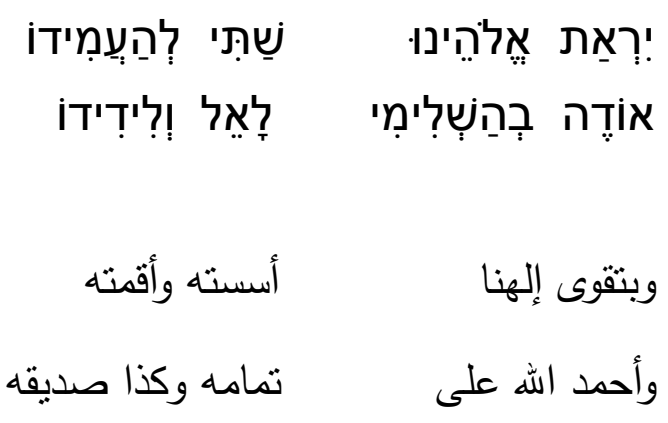


الوزن هو أعظم أركان حد الثـعر، وهو إيقاعه الذي يُطرب، وموسيقاه التي تجذب. لذا أباح النقاد للثـاعر إذا أراد بناء قصيدته أن يفكر في المعنى الذي يريده وأن يُعد أندان له الوزن الذي يطيب لـه القول فيه ('). وبالنظر في قصـائد هذا القسم من أثـعار إبراهيم بن عزرا يثبت لدينا أن شاعرنا قد ألزم نفسـه بحور الثعر التقليدية التي نقلها الأدباء اليهود عن العرب ولم يتجاوزها، فليس في هذه المجموعة قصيدة واحدة نظمها الثـاعر في وزن المقاطع والحركات، ولا بطريقة التوشيح الثـائعة في الأندلس. وإنما ألفيناه يسبح في خمسة بحور هي الوافر ، الكامل، والهزج، والطويل، والبسيط. ولمـا كان الوافر لم يرد صحيحاً في الثعر العربي، إذ لابد من قطف عروضـه (التفعيلة

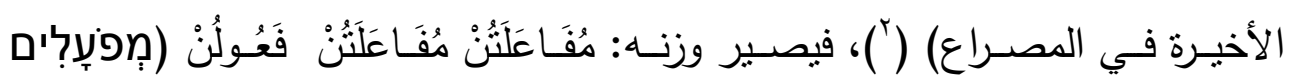

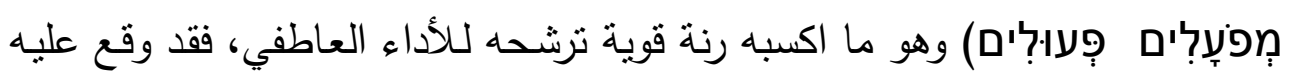
اختيار الثـاعر في نظم ستٍ من قصائده هي: الأولى، والثانية، والسـابعة، والثامنـة،

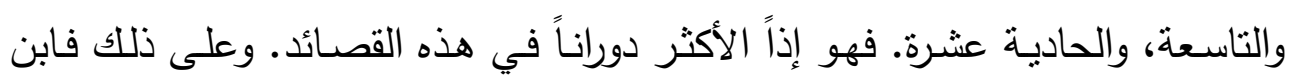
عزرا يسبر مـع عامـة شعراء يهود الأندلس الذين مـالوا إلى بحر الوافر فاستجادوه، ونظموا من خلاله معظم أشعارهم ( )'.

' ابن طباطبا العلوي: عيار الثـعر، تحقيق د/ عبد العزيز المانع، دار العلوم للطباعة والنشر ، الرياض،

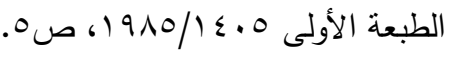
† د إبراهيم الإدكاوي: أوزان الثـعر وقوافيـه- دراسـة وتحليل، مركز معالجـة الوثائق بشبين الكوم، الطبعة

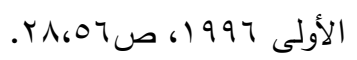

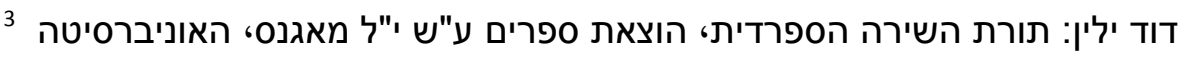

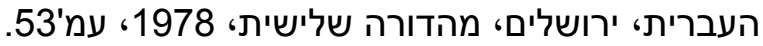


والحـق أن هـا البحر ذو طبيعـة خاصـة حتى في العـروض العربـي، فهو مسـرع النغمات متلاحقها، مسع وقفة قوية سرعان ما يتبعها إسراع وتلاحق، وأكثر ما يكون في نظم الثعراء ذوي الأساليب التي تغلب عليها الخطابة ويتجلى فيها عنصر التكرار والمزاوجـة والمطابقة، والإضـراب عن الثـيء إلى سواه، وعرض جوانب مختلفة من

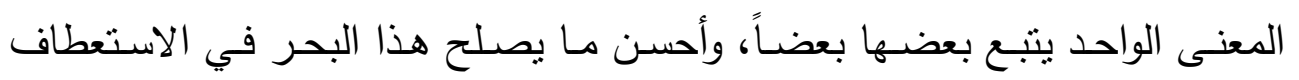
والبكائيات وإظهار الغضب في معرض الهجاء والفخر ، والتفخيم في معرض المدح ('). يلي الوافر بحر الكامل، وقد نظم فيه قصيدتين هما الخامسة والسادسـة. وبحر الكامل هذا هو أكثر البحور جلجلة وحركات، وفيه جرس موسيقي خاص، وهو بحر

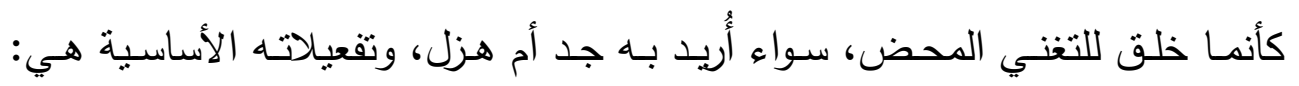

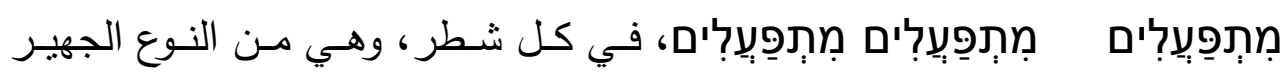
الواضح، الذي يهجم على السامع مع المعنى والعواطف والصور حتى لا يمكن فصله لهابه عنها بحال من الأحوال(r). وهو كما يثنير دفيد يلين يأتي في المرتبة التالية لبحر

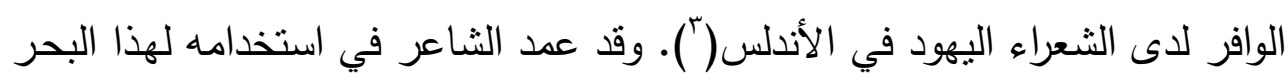

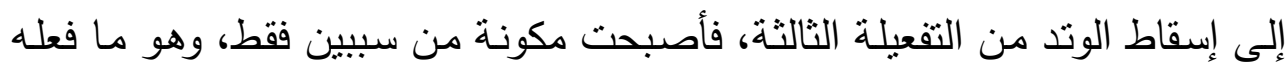
في قصيدته الخامسـة، حيث أصبح الوزن فيها: ثـائي التفعيل أي أنها ورد مجزوءاً،

وأيضاً: د/شعبان محمد سلام: الأثر العربي في الثعر العبري- الجزء الأول في البحور والأوزان، القاهرة .1 19961911

' د دعبد اله الطيب: المرشد إلى فهم أثنعار العرب وصناعتها، دار الفكر للطباعة والنشر والنتوزيع، بيروت،

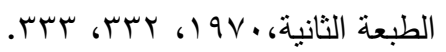

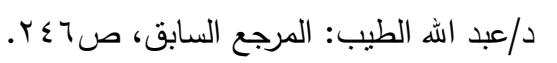


وكانت العرب تهزج بـه لأنـه نوع من الغناء('). وهو يأني في المرتبـة الثالثة لدى شعراء يهود الأندلس بعد الوافر والكامل (").

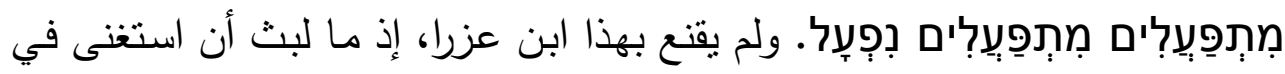

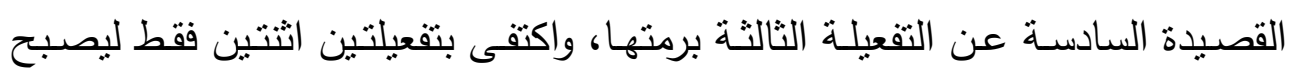

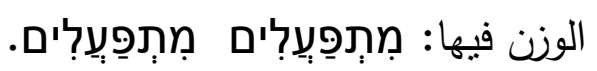
وإلى جانب هذين البحرين نظم شـاعرنا قصائده الثلاثة الباقية وهي الثالثة، والرابعة،

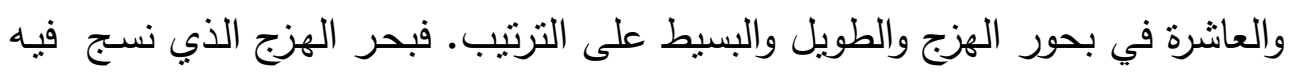

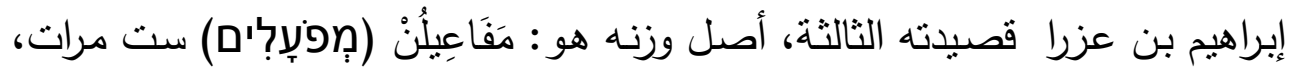
ولكن المستعمل منه في الثعر العربي قديمه وحديثه والطويل والبسيط هما أطول بحور الثعر العربي وأعظمها أبهة وجلالة، وإليهما يعمد

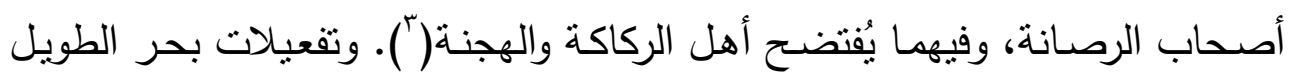

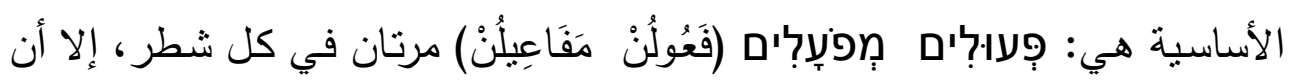

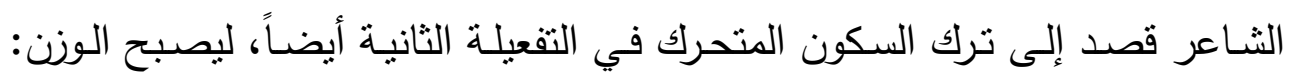

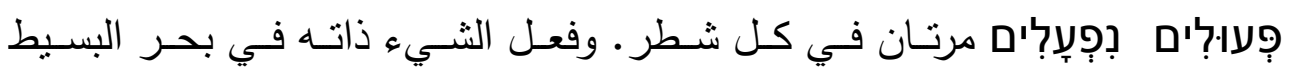

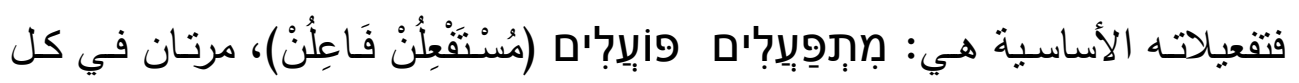

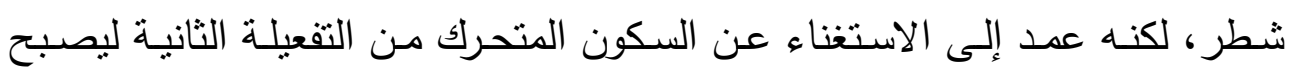

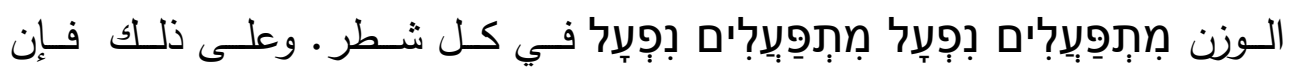

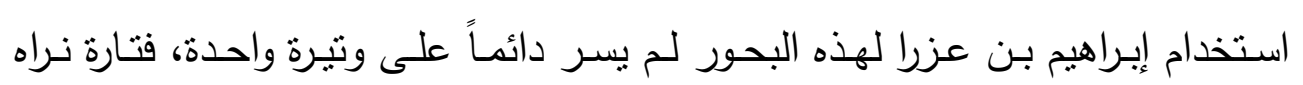

$$
\text { ' د/ إبراهيم الإدكاوي: أوزان الثعر وقوافيه- دراسة وتحليل، صبمى }
$$

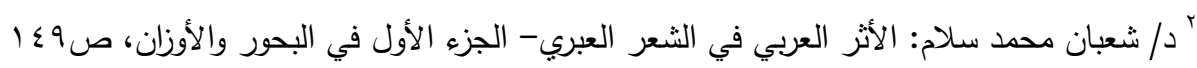

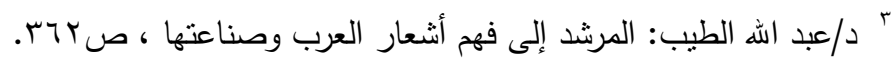


محافظاً على تفعيلات البحور كما فعل في الوافر والهزج. وتارة أخرى يتصرف في تفعيلات بحوره، وهو ما حدث في بحور الكامل، والبسيط والطويل. وإذا كان من فائدة جناها ابن عزرا جراء اختصاره تفعيلات بعض البحور على النحو الذي أسلفنا، فإن هذه الفائدة تكمن بشكل أساسي في تحسين الإيقاع، فقد زاد الجرس الموسيقي لهذه القصائد بشكل ملحوظ، وبخاصة في قصيدته العاشرة. ومع التسليم بأن ابن عزرا كان حريصاً في معظم هذه القصائد على اتساق الوزن مـع

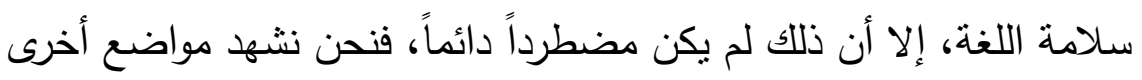

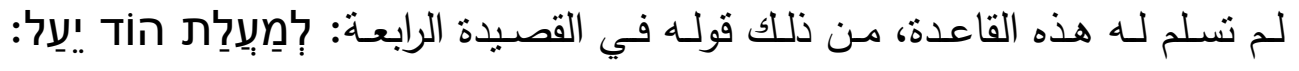

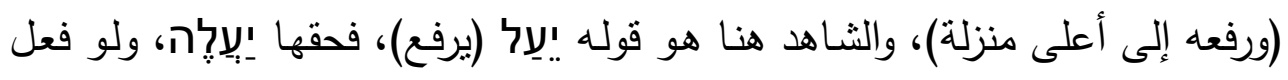

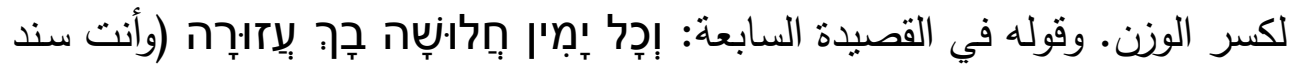
لكل ضعيف)، والثـاهد هنا قوله: جِך وحقها جִּך حيث الخطاب للمذكر • وقولـه في

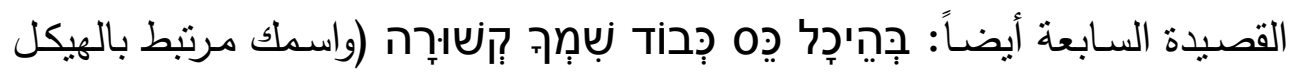

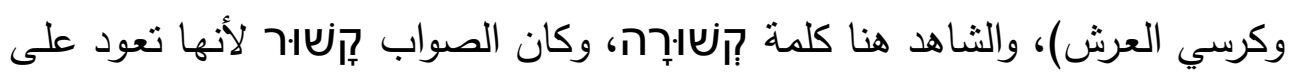
نשִמְך وهو مذكر وليس مؤنثاً.

ثانيا: القافية:

القافية في علم العروض العربي هي عدة أصوات تتكرر في أواخر أبيات القصائد، وكما عرفها الخليل بن أحمد هي: الساكنان وما بينهما مع المتحرك الذي قبل الساكن الأول، أو بعبارة أخرى: هي الحروف التي تبدأ بمتحرك قبل أول سـاكنين في آخر

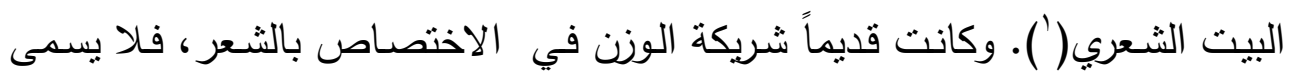


شعراً ما ليس له وزن وقافية('). وظلت الغالبية العظمى من الثعراء والنقاد حتى عهد

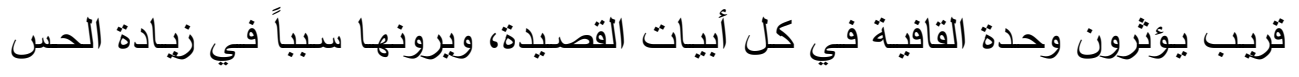

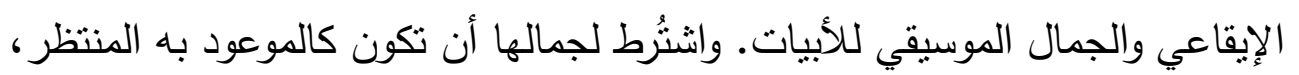

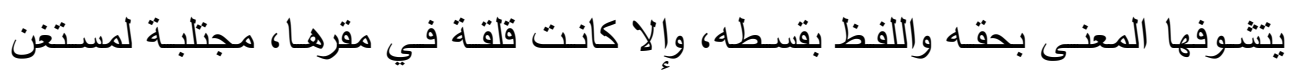
عنها) (r)

والقوافي في العبريـة أحصـاها النحسي اليهودي ديفيد بـن يحيـي في كتابـه "وزن

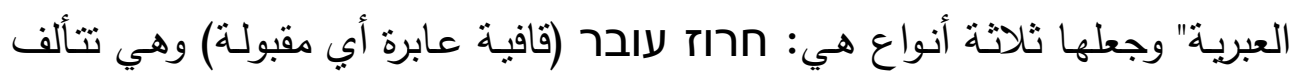
من حرف وحركة، و חרוז ראוי (قافية مناسبة) وهي تتألف من حرفين

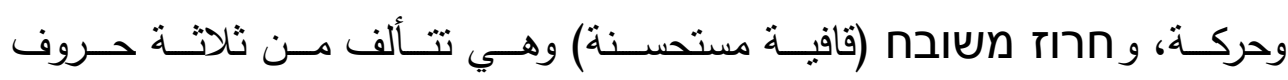

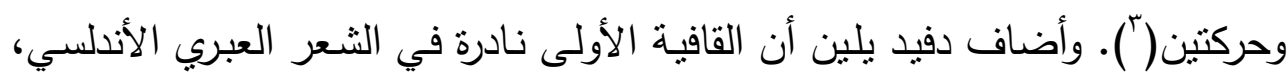

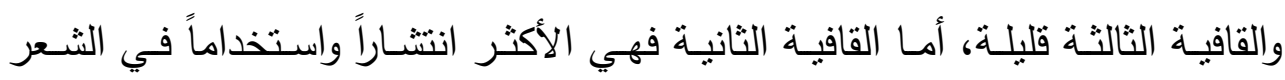

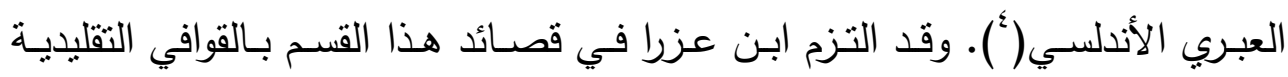

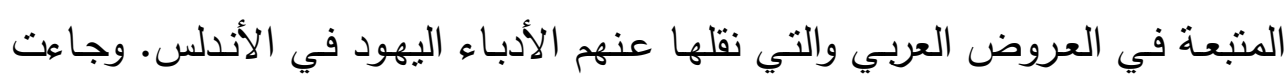

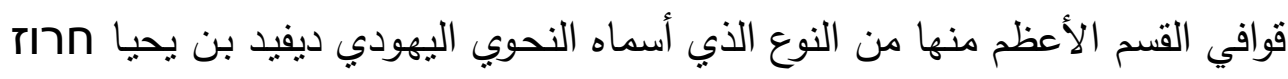
ראו' (قافية مناسبة)، أي التي نتألف من حرفين وحركة، وهو ما يتمثل في قصائده

' أبو علي الحسن بن رشيق القيرواني: العمدة في محاسن الثعر وآدابه ونقده، حققه وعلق عليه محمد محي

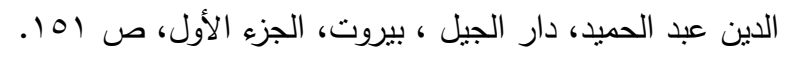

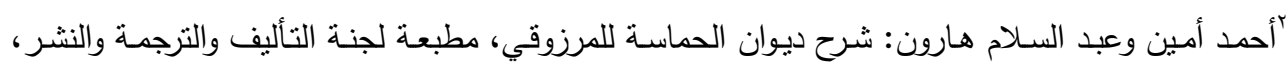

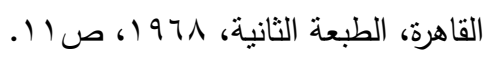

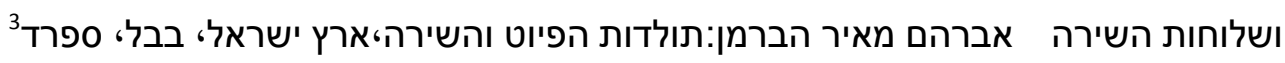
260. ، 1970259،עמן הוצאת מסדה ‘ת"אי הספרדית، בכלי

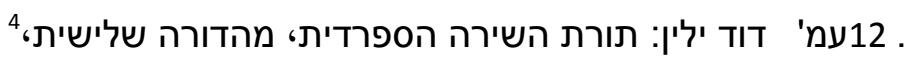


الأولى، والثالثة، والخامسـة، والسادسـة، والسـابعة، والتاسـعة، والعاشـرة. أمـا قصيدتاه

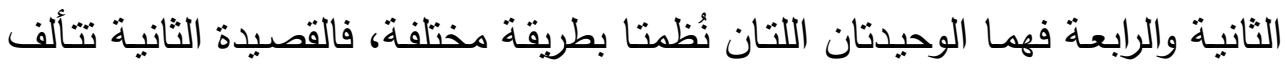
من بيتين لكل منهما قافية مختلفة عن قافية البيت الآخر، وهذا تقليد لم يكن شائعاً

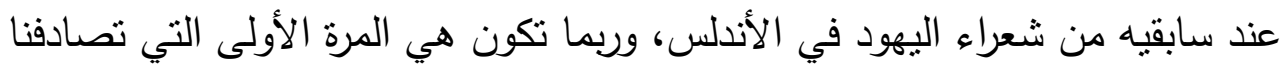

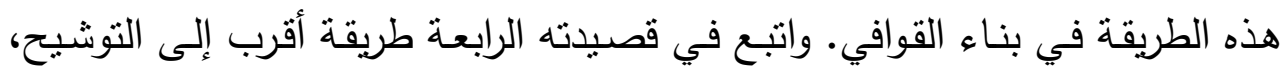

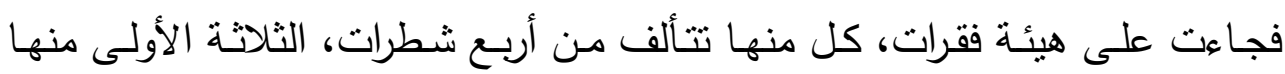

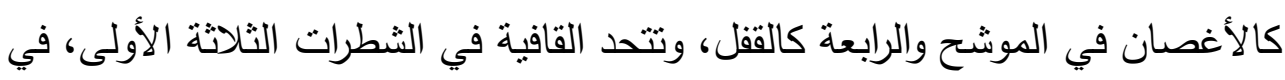

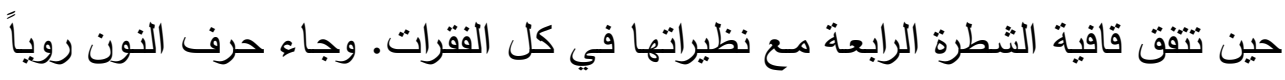

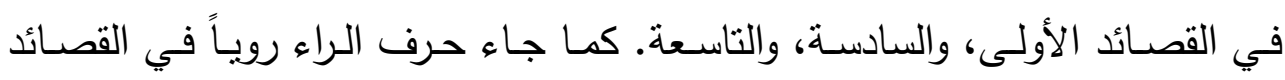

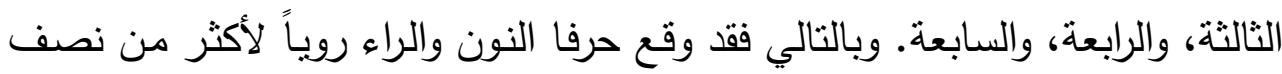

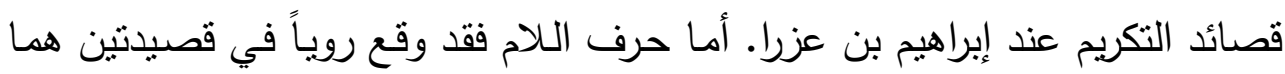
الثانية والرابعة. وعلى كل حال فإن حروف النون والراء واللام هي من أكثر حروف

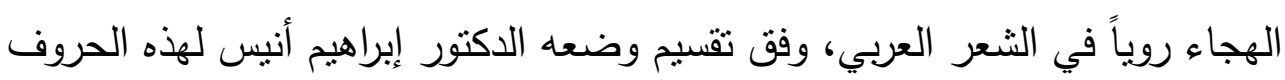

$$
\text { ونسبة ورودها روياً ('). }
$$

واللافت أن معظم قوافي قصائد هذا القسم لإبراهيم بن عزرا من النوع المطلق، أبي

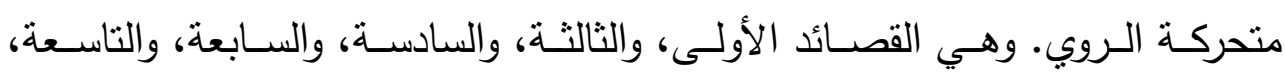

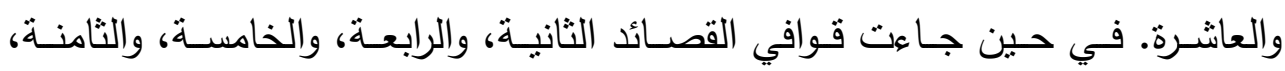
والحادية عشرة من النوع المقيد. ومعروف أن الروي المتحرك أجدى نفعاً لأن تأثيره

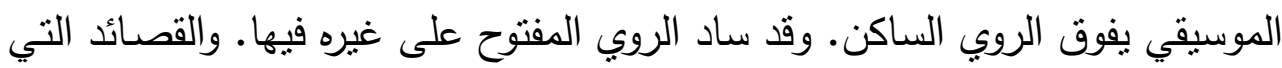

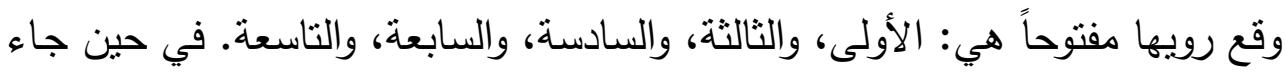

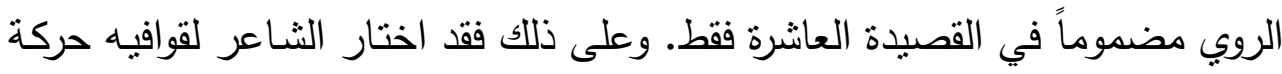

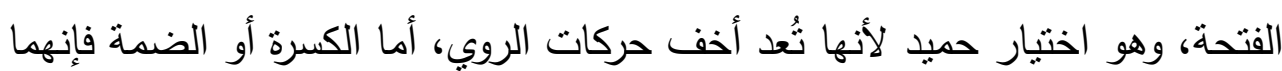


ثقيلتان إذا وقعتا في الروي ('). والتصريع هو أقدم ما نعرف من القوافي الداخلية،

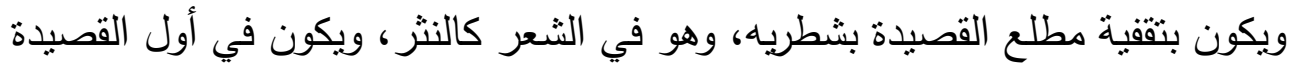

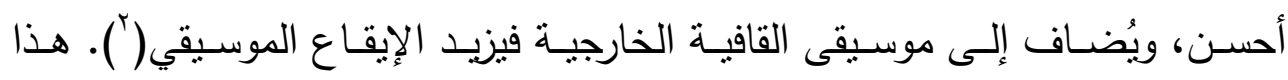

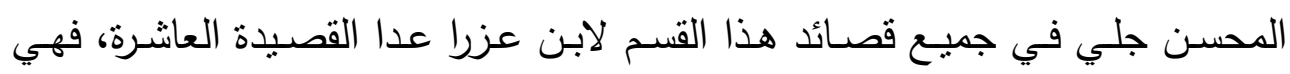
الوحيدة التي خلت من هذا اللون البديعي المتعلق بمطلع القصيدة.

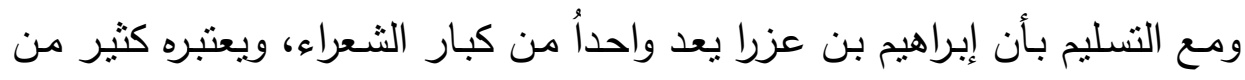

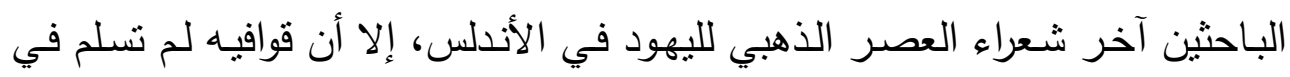

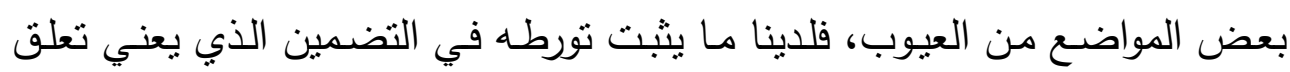

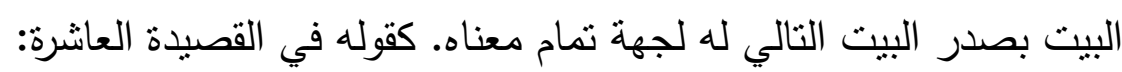

$$
\begin{aligned}
& \text { רָאוּי וְלִיפְִקידוֹ }
\end{aligned}
$$

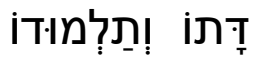

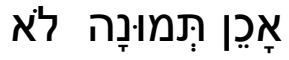

$$
\begin{aligned}
& \text { ولمبعوثه }
\end{aligned}
$$

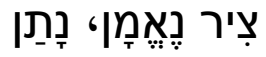

$$
\begin{aligned}
& \text { دينه وتلموده } \\
& \text { ولكنهم لم يشاهدوه، }
\end{aligned}
$$

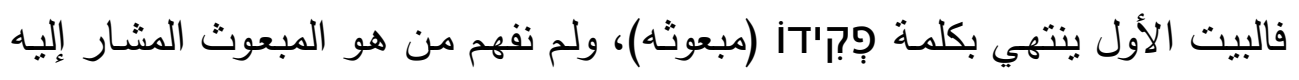

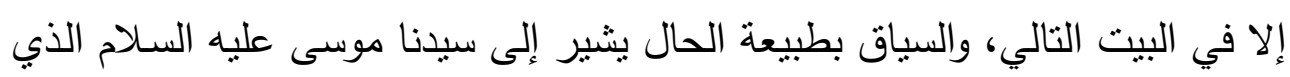
أنزل الله عليه كتابه التوراة. ونحو ذلك أيضاً قوله في القصيدة الثالثة:

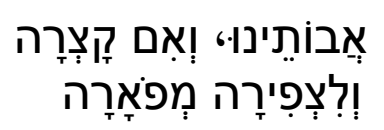

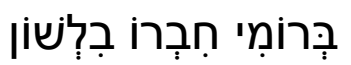

$$
\begin{aligned}
& \text { آبائنا، وإن عجزتُ } \\
& \text { وإكليال رائعا }
\end{aligned}
$$

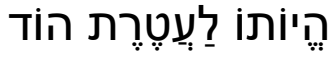

$$
\begin{aligned}
& \text { ألفه في روما بلغنة } \\
& \text { عن جعله تاجاً جميلاً }
\end{aligned}
$$

فالبيت الأول غير مكتق بذاته، وإنما يحتاج إلى البيت التالي له لتتمة الخبر ، وليتبين

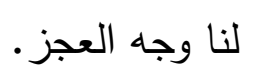

' د د/عبد الله الطيب: المرشد إلى فهم أشعار العرب وصناعتها، ص 79.

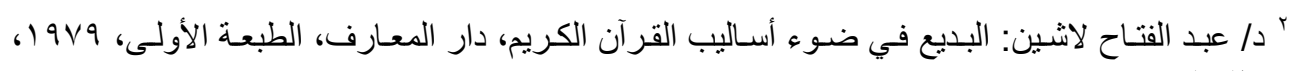


أشعار التكريم عند إبر اهيم بن عزرا

يبقى أن نشير إلى أن بعض قصائد هذا القسم عبارة عن أبيات جميع شطراتها مقفاة

ولا تتوفر هذه المزية إلا في قصيدتيه السادسة والسابعة على وجه الخصوص.

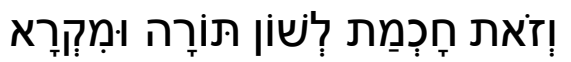

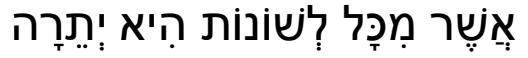

وتلاك حكمة لغة التوراة والعهد القديم

وهي أفضل كل اللغات 


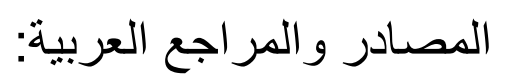

(1) د/ إبراهيم الإدكاوي: أوزان الثعر وقوافيه- دراسة وتحليل، مركز معالجة الوثائق

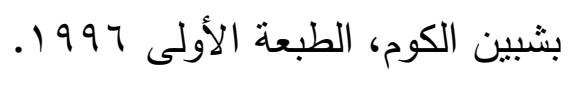

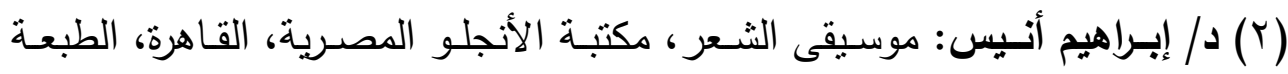

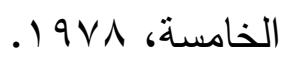

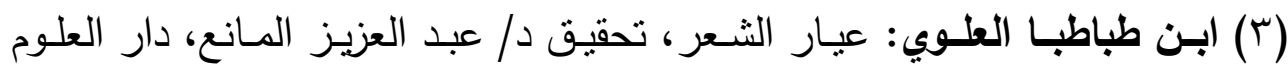

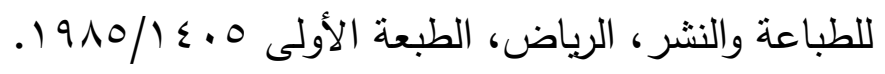

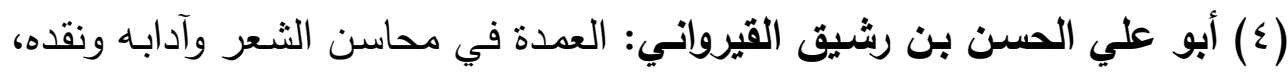

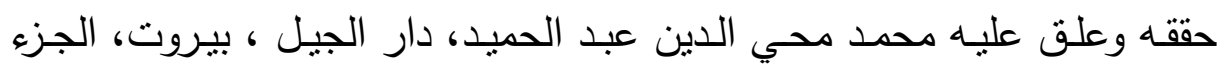

$$
\text { الأول. }
$$

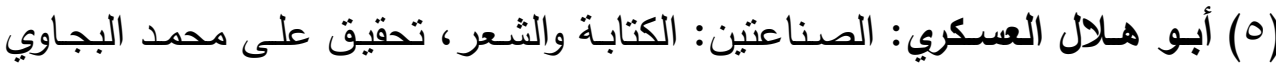

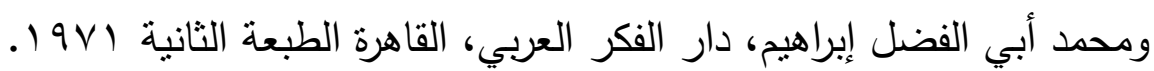

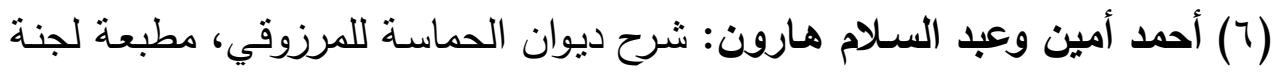

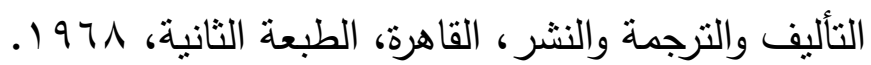

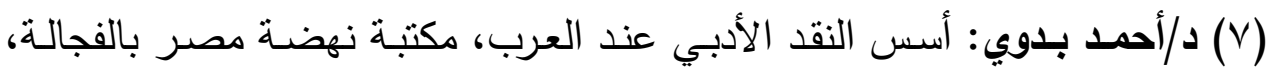

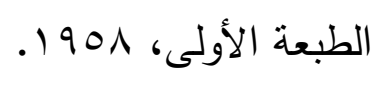

(^) د/ ألفت محمد جلال: الأدب العبري القديم والوسيط، مطبعة جامعة عين شمس،

$$
.19 \vee \wedge
$$

(9) د/ رجاء عيد: فلسفة البلاغة بين التقنية والتطور ، منشأة المعارف ، الإسكندرية،

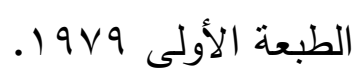

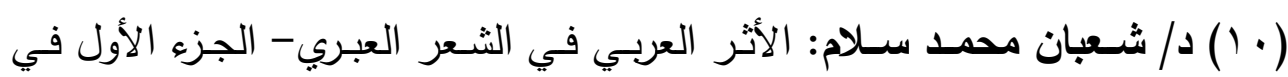

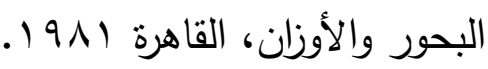

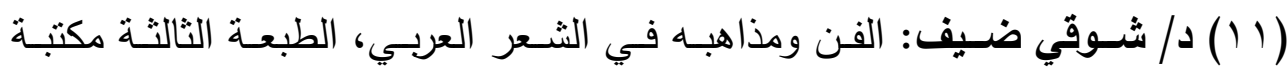

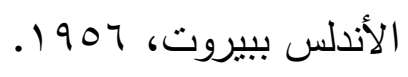




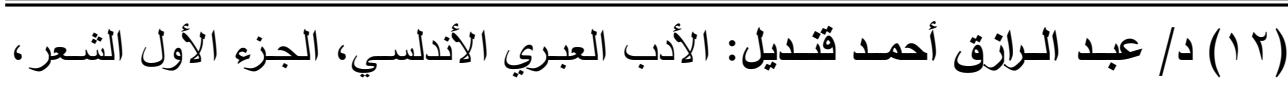

(T ( ) د/ عبد الفتاح لاثين: البديع في ضوء أساليب القرآن الكريم، دار المعارف،

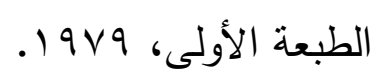

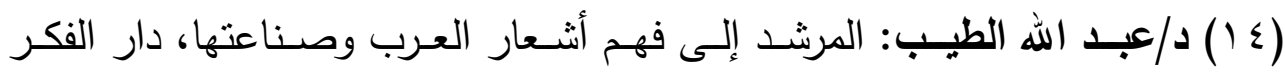

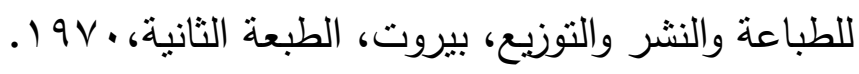

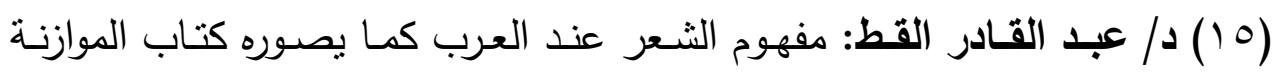

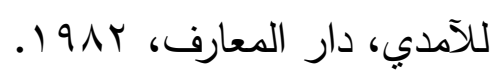

(7 (1) قدامة بن جعفر: نقد الثعر ، تحقيق كمال مصطفى، مكتبة الخانجي، القاهرة،

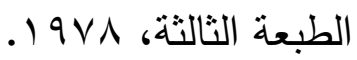

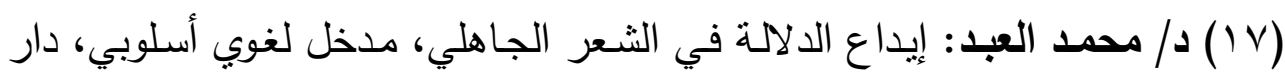

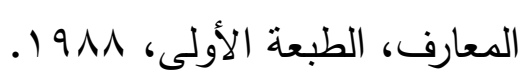

(11) د/ محمد بحر عبد المجيد: اليهود في الأندلس، الهيئة المصرية العامة للتأليف

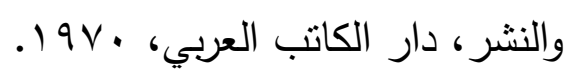

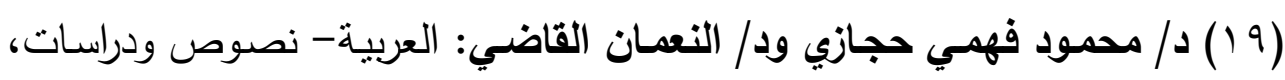

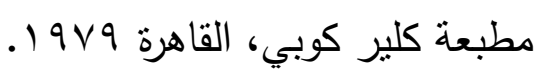


مجلــــة كليـــــــة الآداب

$$
\text { المصادر و المر اجع العبرية: }
$$

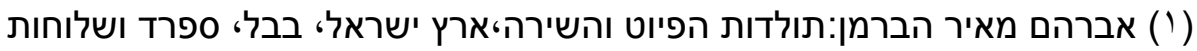
השירה הספרדית، הוצאת מסדה מולתות •ת"אי 1970.

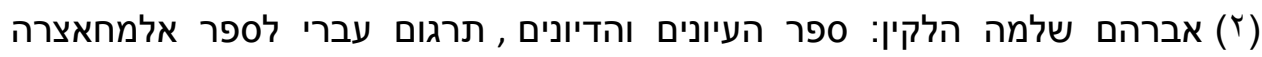
ואל מדאכרה,לר' משה בן יעקב אבן עזרא , מקיצי נרדמים ,ירושלים 1975.

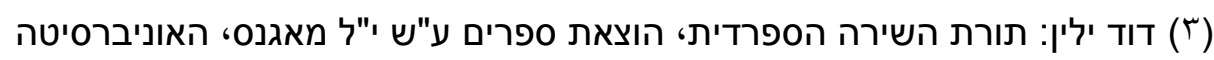
העברית، ירושלים، מהדורה שלישית، 1978.

(§) חיים שירמן: השירה העברית בספרד ובפרובאנס , מוסד ביאליק , ירושלים , דביר

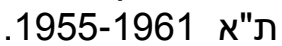

(0) ישראל לווין: אברהם אבן עזרא - שירים '0דרת שירת תור הזהב.

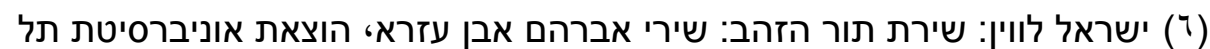
אביב، 2011.

(7) ישראל לווין: שירת תור הזהב: שירי אברהם אבן עזראי הוצאת אוניברסיטת תל

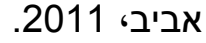

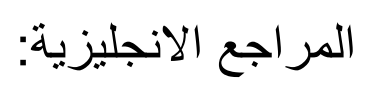

(1) Rene Wellek and Austin Warren: theory of literature. London.1949. 